\title{
Os casos de fuga internacional de escravos e a atuação da Chancelaria brasileira: as negociações com a República da Bolívia entre 1829 e 1870
}

Newman di Carlo Caldeira ${ }^{1}$

\section{Resumo}

Nos primeiros decênios do século XIX, as movimentações internacionais de fuga de escravos em direção à Bolívia passaram a chamar a atenção dos membros do Ministério dos Negócios Estrangeiros do Império do Brasil, em decorrência das constantes reclamações dos proprietários que habitavam, principalmente, a província de Mato Grosso. Por conta da ausência de definições mais precisas quanto ao que poderia ser considerado ilícito internacional, o objetivo deste trabalho será demonstrar o desenvolvimento do processo de legitimação e defesa da propriedade escrava, por parte do Brasil, em seus contatos internacionais. O desenrolar das negociações diplomáticas entre Brasil e Bolívia irá aclarar a contradição existente na aplicação dos direitos de propriedade e de liberdade. Enquanto os representantes do Império brasileiro pediam a devolução dos prófugos asilados, o governo boliviano apontava a inexistência de convenções ou tratados específicos sobre o assunto.

Palavras-chave: Diplomacia, Escravidão, Fronteiras

\begin{abstract}
In the first decades of the nineteenth century, the international movement of slave fleeing towards Bolivia began to draw the attention the Ministry of Foreign Affairs of the Empire of Brazil's members because of the constant complaints from owners who inhabited mainly the province of Mato Grosso. Due to the absence of more precise definitions as to what could be considered illegal international, the goal of this work is to show the development of the legitimation and defense of slave ownership process, by Brazil, in their international contacts. The conduct of diplomatic negotiations between Brazil and Bolivia will clarify the contradiction in the application of the property and freedom rights. While representatives of the Brazilian Empire sought the return of
\end{abstract}

\footnotetext{
${ }^{1}$ Docente da área de História da América da Universidade Federal de Uberlândia - campus do Pontal, Brasil. E-mail: newmancaldeira@yahoo.com.br

Revista Eletrônica da ANPHLAC, ISSN 1679-1061, n.15, p. 37-78, jul./dez. 2013. http://revista.anphlac.org.br/
} 
refugees seeking asylum, the Bolivian government pointed to the lack of specific conventions or treaties on the subject.

Artigo recebido em: 28/06/2013

Artigo aprovado em: 05/11/2013

Keywords: Diplomacy, Slavery, Borders

No ano de 1825, ocorreram intensas transformações no território que viria a ser conhecido como Bolívia. Ao término dos conflitos, as tropas realistas encontravam-se isoladas e sem condições de evitar a derrota para os que lutavam a favor da separação da América do Sul em relação à Espanha². Esse momento de insegurança em relação à afirmação da independência aparece atrelado a expressões de radicalismo, que acabaram fundamentando os processos de proibição do tráfico negreiro e abolição do regime de trabalho escravo. Ambas as decisões foram ratificadas pela primeira constituição política, redigida por um dos mais ilustres próceres das independências sul-americanas - Simon Bolívar-, em 18263. Como veremos ao longo deste trabalho, as disputas provenientes das tentativas de afirmação dos projetos políticos por parte das elites dirigentes em suas respectivas áreas de influência, produziram, mesmo que de modo indireto, reflexos sentidos em contextos diversos. Um exemplo bastante significativo são os processos de abolição dos regimes escravocratas ocorridos nas nações limítrofes e suas consequências para o Império do Brasil.

De acordo com as fontes coligidas, o debate diplomático entre Brasil e Bolívia, a respeito do asilo territorial que aquele governo passou a conceder aos escravos que fugiam em direção à Bolívia, teve início em 1829, quando Duarte da Ponte Ribeiro deu início à série de reclamações acerca da prática de acoitar os cativos oriundos do lado brasileiro. Alguns anos mais tarde, em 1832, o governo boliviano patrocinou a publicação do periódico El Boliviano, que continha a reprodução integral de um decreto

\footnotetext{
${ }^{2}$ Legação Imperial Brasileira (LIB) em Lima In: Arquivo Histórico do Itamaraty (AHI) (212/02/05). Ofício s/n, de 20/3/1839.

${ }^{3}$ Esta afirmativa pode ser mais bem compreendida a partir do famoso Discurso sobre el proyecto de Constitución para Bolivia, no qual Simón Bolívar se propôs a traçar os preâmbulos que deveriam nortear as instituições políticas e sociais do país nascituro.

Revista Eletrônica da ANPHLAC, ISSN 1679-1061, n.15, p. 37-78, jul./dez. 2013.

http://revista.anphlac.org.br/
} 
presidencial, autorizando o poder executivo a prestar uma ajuda financeira aos emigrados que encontrassem dificuldades para se estabelecer em território boliviano. Na prática, a iniciativa acabou confirmando a intenção dos governantes de adotar uma política de acolhimento dos indivíduos provenientes das demais nações sul-americanas. Cabe lembrar que a opção de migrar para a Bolívia não foi uma exclusividade dos cativos brasileiros, uma vez que também englobava homens livres de diferentes estirpes e que disputavam a hegemonia dentro dos cenários políticos de seus locais de procedência. A seguir, reproduzimos o trecho da norma que parece favorecer a entrada

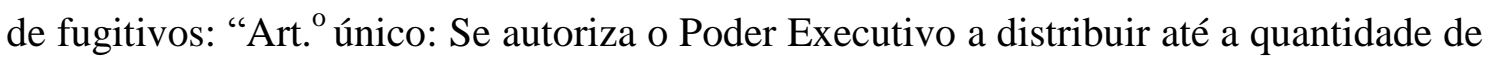
dez mil pesos no presente ano de mil oitocentos e trinta e dois, em auxílio dos asilados nesta república, vindos dos demais Estados americanos"

No mesmo ano, foi publicado um opúsculo governista chamado Memoria presentada por el Ministro del Interior a las Camaras Constitucionales de Bolívia. Essa publicação continha uma seção especificamente para tratar da situação dos asilados. Nesse sentido, o tópico Emigrados procurava demonstrar que a postura assumida pelos governantes bolivianos teria sido implementada com a intenção de evitar que, tanto os refugiados "argentinos", quanto os desgraciados acometidos pela má-sorte da escravidão sofressem agressões ${ }^{5}$. Dessa forma, a existência do direito de asilo passou a ser justificado, no plano ideológico, pelo governo, como uma espécie de prestação de serviço à causa americana. Reproduzimos a seguir, uma das passagens mais importantes do opúsculo que, sem dúvida, ajudou a difundir a imagem da Bolívia como um Estado comprometido com a defesa das liberdades pessoal e de opinião.

Deve ser a Bolívia a pátria comum do gênero humano, a de todo trabalhador,
o asilo de todo desgraçado e a terra da virtude. Venham para o nosso solo,
independentemente do clima que partilham, tenham esta ou aquela religião,
exerçam este ou aquele trabalho, estenderemos sempre uma mão amiga e
hospitaleira para aqueles que queiram entrar em nosso solo. Não
molestaremos jamais os estrangeiros em seus direitos e garantías.

\footnotetext{
${ }^{4}$ LIB em Chuquisaca. In: AHI (211/01/18). Ofício n ${ }^{\circ} 3$, de 27/9/1832, contendo uma cópia do periódico El Boliviano, no 161, publicado em Chuquisaca no dia 4/10/1832. Tradução livre.

${ }^{5}$ LIB em Chuquisaca. In: AHI (211/01/18). Ofício n ${ }^{\circ} 3$, de 27/9/1832, contendo uma cópia do opúsculo Memoria presentada por el Ministro del Interior a las Cámaras Constitucionales de Bolívia (1832). Seção Emigrados, p. 37.

${ }^{6}$ LIB em Chuquisaca. In: AHI (211/01/18). Ofício n 3, de 27/9/1832, contendo uma cópia do opúsculo Memoria presentada por el Ministro del Interior a las Cámaras Constitucionales de Bolívia (1832). Seção Estranjeros, p. 31. Tradução livre.
}

Revista Eletrônica da ANPHLAC, ISSN 1679-1061, n.15, p. 37-78, jul./dez. 2013. http://revista.anphlac.org.br/ 
Entretanto, resta saber como poderiam os dirigentes bolivianos legitimar a concessão de asilo para os cativos que praticavam as fugas internacionais. Em um primeiro momento, o acolhimento foi consubstanciado pela possibilidade de aplicação do princípio de solo livre. A sequência dos debates diplomáticos revelou que os bolivianos sofisticaram suas negativas de extradição, a partir de uma percepção mais apurada acerca das instabilidades políticas que passaram a ocorrer em diversas partes do Império do Brasil, especialmente no Período Regencial (1831-1840). A partir daí, os dirigentes bolivianos adotaram o argumento de que a devolução dos escravos poderia acarretar a aplicação de severas punições, se acaso fossem aplicadas as leis existentes no Império do Brasil ${ }^{7}$. Por esse motivo, os governantes resolveram equiparar a situação dos cativos à dos asilados políticos. A rebelião regencial indiretamente mencionada foi a Cabanagem, rebelião de cunho popular, que ocorreu na província do Pará, entre os anos de 1835 e 1840 (SALLES, 1988, p. 72-74).

A violenta repressão das tropas legalistas contra os cabanos produziu um grande número de baixas - aproximadamente 30 mil pessoas - e, na esperança de escapar das regiões de conflito, parte da população local traçou rotas de fuga que redundaram na ligação de regiões geograficamente distantes ${ }^{8}$. Podemos citar, entre as consequências mais imprevisíveis e pouco trabalhadas pela historiografia, as tentativas das populações locais de arranjar novos locais de habitação. Logicamente, a preferência era dada a regiões afastadas das zonas de batalha, das possibilidades de recrutamento ou do exercício de um controle mais rígido por parte das autoridades provinciais ${ }^{9}$. Nesse sentido, a amplitude de tais movimentações foi múltipla e chegou a incluir tanto movimentações de fuga caracterizadas como "internas", ou seja, casos de evasão que ocorriam dentro das próprias províncias de origem dos prófugos - ou dos domínios territoriais do Império brasileiro (RICCI, 2007, p. 28) -, como "externas" ou internacionais (MACHADO, 2013).

\footnotetext{
${ }^{7}$ LIB em Chuquisaca In: AHI (410/01/05). Nota ${ }^{\circ} 8$, de 12/2/1837.

${ }^{8}$ Entre os autores que ressaltaram as possibilidades de contato entre regiões distantes a partir do chamado "tráfico de ideias", estão: FREITAS (2005); SALLES (2001).

${ }^{9}$ AHI 308/04/12 - Aviso s/n, de 7/3/1836. O contato com as fontes primárias permite notarmos o esforço feito pelas autoridades para arregimentar tropas para combater os "facciozos" cabanos.
}

Revista Eletrônica da ANPHLAC, ISSN 1679-1061, n.15, p. 37-78, jul./dez. 2013. 
No caso do Pará, localizamos informações de que os fugitivos passaram a se fixar ao longo do curso dos rios Madeira e Mamoré, que franqueavam acesso à cidade de Mato Grosso. As autoridades mato-grossenses consideravam extremamente grave a possibilidade de que indivíduos dotados "com ânimos baixos e turbulentos" pudessem chegar à vila de Diamantino, por meio dos rios Tapajós e Arinos ${ }^{10}$. A troca de avisos entre os presidentes das províncias do Pará e de Mato Grosso indica que houve a formação de quilombos nas regiões que passaram a ser ocupadas pelos fugitivos. Depois de chegar a Mato Grosso, alguns prófugos fizeram a opção de seguir em direção ao departamiento de Santa Cruz de la Sierra, localizado na porção oriental da República da Bolívia. Em relação aos caminhos trilhados pelos cativos, tanto a correspondência trocada entre os membros do Ministério dos Negócios Estrangeiros quanto à dos presidentes de província demonstra que parte dos escravos que cruzava as linhas de fronteira não seria, necessariamente, oriunda das províncias mais próximas dos locais de refúgio.

Ao falar especificamente das movimentações internas, notamos que o presidente da província de Mato Grosso, Antônio Pedro de Alencastro, demonstrava grande preocupação com a possível chegada dos "anarquistas do norte". Por esse motivo, Alencastro resolveu convocar a reunião de uma tropa formada aparentemente apenas por cidadãos. Essa nova milícia passou a contar com poder de polícia e foi chamada Cívicos da Reserva. Uma das principais atribuições da tropa seria zelar pela tranquilidade pública em Cuiabá e repelir a entrada dos indivíduos classificados nos documentos de época como "anarquistas desprezíveis"11. A referência não poderia ser mais precisa, pois esclarece que se tratava de pessoas que migravam do Pará. Em última instância, a formação da milícia, em 1835, parece indicar que os fugitivos vinham tentando penetrar - ou efetivamente adentravam - o território de Mato Grosso há algum tempo (RIBEIRO, 2005, p. 135-139) ${ }^{12}$.

Talvez essa tenha sido uma das razões para que o presidente Alencastro passasse a tentar barrar a entrada na província de "homens de cor", orientando as autoridades a não aceitar os "que chegassem de fora do Brasil quando, no seu passaporte, não viesse

\footnotetext{
${ }^{10}$ AN - (IJ ${ }^{1}$ 918). Aviso n ${ }^{\circ} 50$, de Cuiabá em 16/6/1835.

${ }^{11}$ AN - $\left(\right.$ IJ $\left.^{1} 918\right)$. Aviso n ${ }^{\circ} 52$, de Cuiabá em 30/6/1835.

12 Este autor demonstra a importância da Guarda Nacional e dos milicianos na manutenção da ordem. Sobre o mesmo assunto, ver: RODRIGUES; FALCON; NEVES (1981).
}

Revista Eletrônica da ANPHLAC, ISSN 1679-1061, n.15, p. 37-78, jul./dez. 2013. http://revista.anphlac.org.br/ 
declarada sua qualidade de ingênuo e, assim, abonada pelos cônsules e Encarregados de Negócios do local de origem" "13. Na passagem anterior, fizemos questão de frisar a parte que estabelece a pré-condição de entrada dos indivíduos "de cor" na província, para destacar a necessidade de os mesmos serem ingênuos e não libertos. Esse ponto parece ser extremamente revelador, na medida em que os dirigentes provinciais tentavam afastar a possibilidade de retorno aos locais de origem dos "libertos por asilo". O convívio em liberdade dos mesmos com os demais precisava ser evitado a todo custo, em virtude do exemplo que os antigos fugitivos forneceriam aos demais. Nesse sentido, a nova condição legal dos "ex-cativos" seria a prova da existência de um tipo de libertação, que fugiria dos padrões legais estabelecidos e/ou aceitos judicialmente.

O retorno dos asilados ao território brasileiro criava uma situação não prevista pelos quadros da legislação imperial, uma vez que as autoridades passavam a ter de lidar com o dilema de reconduzir um escravo fugitivo ao cativeiro ou respeitar o documento apresentado pelos "retornados" que, em teoria, seria suficiente para garantir o direito de permanecerem em liberdade. O escopo de uma das intrigantes questões que ora se apresentavam pode ser resumido da seguinte maneira: como poderiam os asilados pensar na possibilidade de voltar a viver em território brasileiro, se, aos olhos das autoridades, os mesmos permaneciam gozando da condição de cativos? Essa resposta pode ser encontrada justamente na possibilidade de aquisição, por parte dos prófugos escravos, quando em solo boliviano, dos passaportes legais. $\mathrm{O}$ trecho da fonte citada no parágrafo anterior deixa entrever que os ex-cativos se apresentavam às autoridades imperiais munidos desse tipo de documento, o que lhes garantia o gozo de uma cidadania que diferia da brasileira.

Nesses casos, as autoridades provinciais certamente deveriam passar a agir com cautela, uma vez que os atos de reescravização dos "libertos" poderiam suscitar a abertura de uma frente de debates internacionais, motivada pela acusação de que haviam desrespeitado os direitos de um cidadão estrangeiro. De todo modo, a exigência de apresentar o passaporte no momento da travessia certamente não fornecia as necessárias garantias de que seus portadores seriam quem realmente diziam ser. O acesso dos cativos fugitivos às autoridades bolivianas responsáveis pela emissão desse tipo de

\footnotetext{
${ }^{13} \mathrm{AN}-\left(\mathrm{IJ}^{1}\right.$ 918). Aviso $\mathrm{n}^{\circ}$ 58, de Cuiabá em 11/8/1835. Grifo nosso.

Revista Eletrônica da ANPHLAC, ISSN 1679-1061, n.15, p. 37-78, jul./dez. 2013.

http://revista.anphlac.org.br/
} 
documento continuará sendo um mistério, pois não temos como precisar - com as fontes atualmente disponíveis - as formas encontradas pelos prófugos para conseguir tais papéis. Em meio às investigações, localizamos uma Ordem, publicada no dia 27 de junho de 1833, que procurava normatizar a emissão dos passaportes para o exterior ${ }^{14}$. Para tanto, o governo central tornou privativa a emissão dos passaportes para o exterior, ao determinar que corregedores e governadores ficassem impossibilitados de emiti-los.

Em relação aos passaportes legais, entendemos ser necessária a realização de investigações complementares, por acreditarmos que os mesmos possam revelar a existência de alguma estratégia dos retornados, no sentido de manipular as próprias identidades, a fim de obterem vantagens em relação à condição que gozavam antes da fuga. Porém, neste momento, podemos apenas tecer considerações sobre um ponto extremamente importante, ou seja, a possibilidade de utilização da condição de cidadão naturalizado para reivindicar o reconhecimento - por parte dos agentes do Estado brasileiro - de que a mobilidade geográfica efetivamente modificava a condição legal dos fugitivos. Nesse sentido, acreditamos que possa ter havido casos de prófugos escravos, que conseguiram, de alguma forma, mudar, mesmo contra a orientação do aparato jurídico-burocrático das autoridades policiais ou do exército e dos próprios proprietários, as bases que legitimavam a instituição escravista. Entre as plataformas que serviram para operacionalizar uma mudança dessa magnitude, aparece o princípio de territorialidade, que fazia com que a aquisição de um direito dentro de um Estado permanecesse valendo em outro.

\section{O curso das negociações: entre anuências e dissensões em relação à devolução dos cativos asilados}

Passaremos, agora, a analisar os pormenores de um dos episódios que mais contribuíram para acirrar as tensões diplomáticas entre Brasil e Bolívia: a promessa de restituição dos cativos asilados feita pelo vice-presidente da Bolívia, José Miguel de Velasco Franco. Em 1836, Velasco Franco assumiu - por meio de uma nota dirigida ao

\footnotetext{
${ }^{14}$ Archivo Histórico de la Honorable Camara de Diputados. Coleccion Official de Leyes, Decretos, Ordenes, Resoluciones \&c, años 1833, 1834, y hasta la instalacion del Congreso de 1835. [La] Paz de Ayacucho: Imprenta del Colegio de Artes, 1835. p. 50. Orden de 27 de junio de 1833.
}

Revista Eletrônica da ANPHLAC, ISSN 1679-1061, n.15, p. 37-78, jul./dez. 2013.

http://revista.anphlac.org.br/ 
representante brasileiro ${ }^{15}$ - o compromisso de reforçar a fiscalização da polícia nas faixas de fronteira e extraditar os escravos que buscassem abrigo em solo boliviano. Para atender à nova orientação de seu governo, o titular da pasta das Relações Exteriores, José Ignácio de Sanginés, passou algumas orientações ao prefeito de Santa Cruz de la Sierra. A correspondência do ministro dava recomendações no sentido de garantir que o prefeito passasse a considerar Mariano Ribeiro da Silva Apinagé cidadão brasileiro que residia naquela capital - como "comissário especial"16. Nesse sentido, Apinagé ficava autorizado a identificar e enviar de volta para o território imperial os prófugos escravos que tivessem estabelecido domicílio naquelas paragens.

As dificuldades para a resolução de uma questão que envolvia o título de propriedade de inúmeros interesses de cidadãos brasileiros e bolivianos não chegam a surpreender. Em meio aos processos de negociação, os dirigentes bolivianos passaram a impor algumas ressalvas, com o intuito de dificultar o cumprimento do acordo. Para tanto, as restituições deveriam necessariamente resguardar o direito de propriedade dos bolivianos que tivessem comprado escravos foragidos, até a data de publicação da $\operatorname{circular}^{17}$. Na prática, o efeito desejado seria impossibilitar a fixação de datas com efeito retroativo em relação à extradição dos cativos que tivessem pisado no solo daquela nação, antes da entrada em vigor da circular. Um pré-requisito para a repatriação dos escravos asilados seria o compromisso dos governantes brasileiros de assegurar que a restituição dos prófugos não motivaria a aplicação de castigos físicos ${ }^{18}$.

Algumas das revelações mais interessantes a respeito do esforço conjunto de repatriação dos cativos brasileiros foram localizadas no acervo do Archivo Histórico da Universidad Autónoma Gabriel René Moreno (UAGRM), situado na cidade de Santa Cruz de la Sierra. Em meio às investigações, encontramos indícios de que uma comissão chefiada por Apinagé realmente atuou em solo boliviano ${ }^{19}$. As fontes

\footnotetext{
${ }^{15}$ LIB em Chuquisaca In: AHI (410/01/05). Nota $n^{\circ} 5$, de 18/1/1837.

${ }^{16}$ LIB em Chuquisaca In: AHI (410/01/05). Nota $n^{\circ} 6$, de 11/2/1837.

${ }^{17}$ LIB em Chuquisaca In: AHI (410/01/05). Circular boliviana s/n, de Cochabamba, s/d., do ministro de Estado del Interior ao prefeito do departamiento de Santa Cruz de La Sierra, anexa sob n ${ }^{\circ} 5$, à nota $\mathrm{n}^{\circ} 5$, de 18/1/1837.

${ }^{18}$ LIB em Chuquisaca In: AHI (410/01/05). Nota $n^{\circ} 7$, de 12/2/1837.

19 Archivo Histórico da Universidad Autónoma Gabriel René Moreno (UAGRM) - F/MMC19-L2 Carpeta 19-Legajo 2 - Doc. 1837-1879 - Cartas de Provincias del Brasil enviadas al Gobierno Boliviano. Documento da "Comicion de la Legacion Brasilera en Bolivia", enviado de Santa Cruz de la Sierra em 6/3/1837, do chefe da comissão Mariano Apinagé ao Prefeito do departamiento.
}

Revista Eletrônica da ANPHLAC, ISSN 1679-1061, n.15, p. 37-78, jul./dez. 2013.

http://revista.anphlac.org.br/ 
demonstram que a missão apresentou uma lista às autoridades departamentais, contendo os nomes dos cativos asilados, que incluía até mesmo um escravo foragido da província do Pará. A listagem contendo nove nomes havia sido formulada para facilitar o trabalho de averiguação das autoridades policiais da Bolívia e continha informações a respeito dos locais de procedência dos cativos e de seus respectivos senhores. Os prófugos escravos ainda aparecem divididos entre os que haviam se dirigido para Santa Cruz de la Sierra e os que haviam fugido em direção a Chiquitos ${ }^{20}$.

Um documento revela a sugestão do então presidente da província de Mato Grosso, para que os escravos que se encontrassem na condição de refugiados fossem apreendidos e "aplicados a trabalhos públicos n'essa Capital [Santa Cruz] e em Chiquitos, por tempo conveniente para indenização das despesas ocasionadas por aquela diligencia, depois do que houvessem de ser enviados à Fronteira" ${ }^{21}$. Em outra passagem, o presidente Pimenta Bueno fez considerações no sentido de recomendar às autoridades bolivianas, que os cativos apreendidos fossem conservados na prisão para impossibilitar a fuga. Em carta dirigida ao prefeito de Santa Cruz, o presidente se dispôs a assumir a responsabilidade pelo pagamento de uma indenização, que compensaria as despesas feitas durante as etapas de apreensão, conservação e escolta dos foragidos até a fronteira. Pimenta Bueno ainda dizia ser inadmissível que soldados brasileiros penetrassem armados os territórios bolivianos atrás de prófugos escravos. Nesse sentido, o presidente recomendava que aqueles governantes passassem a reunir e armar uma tropa capaz de executar a tarefa de entregá-los às rodas de Cazalvasco.

As correspondências trocadas entre Apinagé e o encarregado de negócios do Brasil na Bolívia, Duarte da Ponte Ribeiro ${ }^{22}$, revelam que o comissário brasileiro estava autorizado a fazer os gastos que fossem necessários na tentativa de reaver os cativos.

\footnotetext{
${ }^{20}$ UAGRM - F/MMC19-L2 - Carpeta 19-Legajo 2 - Doc. 1837-1879 - Cartas de Provincias del Brasil enviadas al Gobierno Boliviano. Carta de Santa Cruz de la Sierra, enviada no dia 6/3/1837, redigida pelo comissário Mariano Ribeiro da Silva Apinagé, sem indicação precisa do destinatário.

${ }^{21}$ UAGRM - F/MMC19-L2 - Carpeta 19-Legajo 2 - Doc. 1837-1879 - Cartas de Provincias del Brasil enviadas al Gobierno Boliviano. Carta de Cuiabá, enviada no dia 11/5/1838, do presidente da província de Mato Grosso José Antonio Pimenta Bueno para o Prefeito do departamento de Santa Cruz de la Sierra José Miguel de Velasco.

${ }^{22}$ Duarte da Ponte Ribeiro, nascido em 4 de março de 1795 e falecido no dia $1^{\circ}$ de setembro de 1878 , atuou como médico, cartógrafo e diplomata. Foi o primeiro e único barão da Ponte Ribeiro. Na diplomacia, destacou-se, ao propor que o Império do Brasil passasse a negociar suas linhas de fronteira internacional, com base no princípio jurídico de uti possidetis de facto. Embora recusada pelo Parlamento, tempos depois, a proposta se consolidou como doutrina e passou a guiar as ações do governo brasileiro.

Revista Eletrônica da ANPHLAC, ISSN 1679-1061, n.15, p. 37-78, jul./dez. 2013.

http://revista.anphlac.org.br/
} 
Ponte Ribeiro também orientou o comissário a repassar, aos proprietários interessados em reaver seus escravos, os custos referentes à apreensão durante o ato de entrega dos mesmos $^{23}$. Na carta seguinte, o encarregado de negócios aprovou a atitude do comissário de oferecer a prestação de serviço dos asilados pelo período de três meses, em decorrência da anuência dos governantes bolivianos em conceder a extradição dos prófugos asilados ${ }^{24}$. As fontes demonstram que, apesar da distância, os contatos entre Ponte Ribeiro e Apinagé foram bastante frequentes. Entretanto, essa mesma coleção documental acaba deixando em aberto a possibilidade de fazermos ponderações mais exatas, acerca dos reiterados pedidos de devolução dos asilados, que, aparentemente, não foram atendidos pelos dirigentes bolivianos.

Talvez a promessa de restituição dos cativos asilados tenha servido de base para o historiador norte-americano Ron L. Seckinger (1970) afirmar que as fugas internacionais de escravos não chegaram a mobilizar maiores atenções por parte das autoridades brasileiras e bolivianas. De acordo com esse autor, o número de casos era reduzido, e havia um bom nível de colaboração dos dirigentes departamentais, que os extraditavam, sem impor maiores restrições.

\footnotetext{
Depois da independência, a Bolívia passou a adotar a política de abrigar escravos fugitivos do Brasil. Motivado pelo acoitamento dos cativos, o governo brasileiro enviou repetidas reclamações, que foram atendidas pelo governo boliviano. Em 1836, o prefeito de Santa Cruz de la Sierra foi instruído a entregar os fugitivos para os funcionários de Mato Grosso, excetuando apenas os escravos que já tivessem sido vendidos para novos proprietários em Santa Cruz. (p.76-77). ${ }^{25}$
}

Ao problematizar as considerações feitas por Seckinger (1970), notamos que o autor desconsiderou a existência das constantes notas de reclamação do governo imperial. O teor das correspondências revela que os governantes brasileiros haviam passado a protestar abertamente contra a política de acolhimento dos escravos fugitivos, considerada como uma espécie de atentado contra o legítimo direito de propriedade dos senhores. A afirmação do brasilianista parece fazer ainda menos sentido, quando

\footnotetext{
${ }^{23}$ AHI 454-4-17 - Carta $^{\circ}$ 2, de Chuquisaca em 13/2/1837.

${ }^{24}$ AHI 454-4-17 - Carta no $^{\circ}$ 3, de Chuquisaca em 13/3/1837.

${ }^{25}$ A versão apresentada pelo autor baseia-se em pesquisas documentais realizadas no Arquivo Nacional, pasta IJJ-9 505, nota $\mathrm{n}^{\circ} 28$. No anexo I, transcrevemos a versão encontrada no AHI, referente à legação brasileira em Potosi, volume 410/01/05, nota recebida pelo Encarregado de Negócios Duarte da Ponte Ribeiro, sob n ${ }^{\circ}$ 5, em 27/6/1836.
}

Revista Eletrônica da ANPHLAC, ISSN 1679-1061, n.15, p. 37-78, jul./dez. 2013. http://revista.anphlac.org.br/ 
consultamos as séries de avisos do presidente da província de Mato Grosso, que estão sob a guarda do arquivo do Itamaraty. Em meio à troca de expediente entre as diversas autoridades, encontramos, no ano de 1835, uma correspondência, assinada pelos membros da Câmara Municipal da cidade de Mato Grosso, que trazia informações extremamente valiosas. Segundo os relatos, de nada adiantava as autoridades provinciais e particulares recorrerem às diversas instâncias e diferentes autoridades bolivianas, pois os pedidos de restituição dos prófugos escravos eram costumeiramente ignorados.

Nesse sentido, o documento menciona que os fugitivos e o acolhimento das autoridades bolivianas ofereciam a eles serviam de exemplo para os demais escravos. Os membros da Câmara ainda diziam que a pouca distância entre as nações limítrofes, de apenas 15 léguas, juntamente com os auxílios que recebiam, acabavam sendo decisivos para incrementar o número de casos de fuga. Em 1835, os dirigentes matogrossenses estimavam haver mais de 200 escravos brasileiros asilados na República da Bolívia, em virtude da certeza que tinham de que não seriam entregues aos seus senhores. Além dos grandes prejuízos causados diariamente aos proprietários, o comunicado da Câmara ainda acusava que a continuidade das fugas levaria a província à total decadência ${ }^{26}$. Por considerarmos que Seckinger (1970) não tenha conseguido demonstrar, de forma clara, quais foram as bases documentais usadas para apoiar suas afirmações, acreditamos que seus pontos de vista dificilmente possam continuar a ser $\operatorname{sustentados}^{27}$. As fontes diplomáticas apoiam a visão adotada neste trabalho, uma vez que demonstram que o compromisso de devolução não chegou a ser cumprido, ao menos em larga escala, pelos governantes bolivianos.

O acervo do Arquivo Nacional da Bolívia guarda alguns documentos que contribuíram para evitar que também incorrêssemos no erro de simplificar demasiadamente o episódio da promessa de devolução. Em 1833, ou seja, antes de o vice-presidente ter se comprometido a extraditar os cativos, localizamos alguns documentos que mencionam a chegada de quatro cativos fugitivos do Brasil. Consta,

\footnotetext{
${ }^{26}$ AHI 308/02/08 - Governo de Mato Grosso (1823-1838). Aviso s/n, de 13/7/1835, dos membros da Câmara municipal da cidade de Mato Grosso dirigida ao Imperador, anexo ao aviso $\mathrm{n}^{\circ} 5$, de Cuiabá em $14 / 9 / 1835$.

${ }^{27}$ LIB em Potosi In: AHI (410/01/05). Nota $n^{\circ} 18$, de 27/4/1838. Esta nota trata da devolução dos escravos, e constatamos que a mesma não passa de um compromisso aparentemente não cumprido pelo governo boliviano.
}

Revista Eletrônica da ANPHLAC, ISSN 1679-1061, n.15, p. 37-78, jul./dez. 2013.

http://revista.anphlac.org.br/ 
em meio aos registros, que os foragidos se chamavam Quintino, Bento, Eva e Feliciana, e que os mesmos seriam de propriedade do brasileiro Antonio Rodrigues da Costa. A fonte indica que a prefeitura havia deixado a cargo da intendência de polícia a tarefa de permitir que os fugitivos pudessem trabalhar para cidadãos honrados, a fim de conseguir os necessários meios de subsistência. No entanto, as informações prestadas dão conta de que Bento havia sido vitimado por uma peste mortífera, tendo sobrado apenas os outros três asilados em solo boliviano. O ponto que mais surpreende é que o prefeito de Santa Cruz relatava ao ministro do Interior, que tomaria as necessárias providências para a realização da entrega dos refugiados para o cidadão brasileiro Mariano Ribeiro da Silva Apinagé ${ }^{28}$.

Um documento redigido aproximadamente um mês depois, sem indicação precisa da autoria, ou do destinatário, dava ciência de que os escravos pertencentes a Rodrigues tinham efetivamente sido entregues ao brasileiro M. Ribeiro da Silva [Apinagé] $^{29}$. Ao que tudo indica, essa informação possibilita que apontemos a existência de, pelo menos, um caso de devolução de escravos asilados, que haviam buscado o abrigo do solo boliviano, na esperança de melhorar suas condições de vida ou trabalho. No entanto, a repercussão negativa das notas do vice-presidente - que assumiam o compromisso de restituir os prófugos escravos para o governo brasileiro - deixa transparecer que tal resolução havia sido fruto de um entendimento pessoal em relação à questão, e não de um consenso interno, que representasse o desejo das diferentes esferas do governo boliviano. Não há dúvida de que o governo boliviano havia resolvido mudar de postura, já que passou a aplicar a legislação já existente em seu território; e que continha os parâmetros legais que versavam sobre a proibição de extraditar os estrangeiros asilados. A publicação do decreto de 30 de janeiro de 1838 acabou afastando qualquer possibilidade de repatriação dos fugitivos ${ }^{30}$. De acordo com o Código Penal Santa Cruz, de 1836, a República da Bolívia já possuía dispositivos que

\footnotetext{
28 Archivo y Biblioteca Nacionales de Bolivia (ABNB). MI-46-31 - Correspondência $\mathrm{n}^{\circ} 3$, de 12/10/1833, do prefeito de Santa Cruz de la Sierra para o ministro do Interior.

${ }^{29}$ ABNB. MI-69-21 - Correspondência n ${ }^{\circ}$ 106, de 9/11. Aparentemente, a fonte parece ser uma minuta e, por isso mesmo, não trás maiores informações quanto aos nomes dos remetentes, destinatários ou ano de envio.

${ }^{30}$ LIB em Cochabamba. In: AHI (410/01/05). Nota n $\mathrm{n}^{\circ} 21$, de 27/12/1838.

Revista Eletrônica da ANPHLAC, ISSN 1679-1061, n.15, p. 37-78, jul./dez. 2013.

http://revista.anphlac.org.br/
} 
legitimavam a posição adotada pelo governo, de não aceder aos pedidos de repatriação "dos esclavos fujitivos de los Estados vecinos" 31.

As notas trocadas entre o encarregado de negócios do Brasil, João da Costa Rego Monteiro, e o ministro das Relações Exteriores da Bolívia, Andres Maria Torrico, em 1838, demonstram que o ministro passou a embasar as negativas de devolução, a partir da interpretação de que o decreto tinha sido uma "consequência necessária das leis bolivianas". O representante brasileiro não demorou a perceber que o compromisso assumido pelo governo boliviano não seria cumprido e comunicou ao Ministério dos Estrangeiros a existência de matérias legais que tornariam inconstitucional o ato de restituir os fugitivos. O conteúdo da circular deixa claro que o governo boliviano tencionava afastar qualquer possibilidade de a promessa de restituição dos cativos asilados ser cumprida. Abaixo, selecionamos dois fragmentos que elucidam a forma como a questão passaria a ser tratada:

\begin{abstract}
uma das leis que mais honram a legislação boliviana e que tem chamado a atenção do mundo culto sobre suas instituições é o artigo 109 do Código Penal Santa Cruz, que fixou o território boliviano como um asilo inviolável para todo homem que precise do amparo dele, para gozar de sua hospitalidade, proteção, segurança e demais garantias que leis filosóficas e ordenadas pela razão e espírito do século oferecem ao homem estrangeiro, qualquer seja sua cor, origem e criação (...). S. E. não pode permitir que continue a haver a violação do Direito das Gentes, nem que os escravos, que desde que pisam o solo da Bolívia recuperam sua liberdade primitiva, sejam entregues a seus senhores, nem ao governo de outras nações, qualquer que seja o título com que são reclamados; e para que, daqui por diante, essa regra não seja desobedecida impunemente, cabe dizer que, logo que se tenha conhecimento da entrega de escravos asilados nesta República, os indivíduos que tomarem parte na devolução ou que tiverem conhecimento da mesma e não a evitarem serão suspensos do exercício de seus cargos de funcionários públicos; instruída a sumária de acusação, que os autos sejam remetidos para a autoridade competente, para julgamento, e que o castigo seja aplicado ao delinquente. ${ }^{32}$
\end{abstract}

Entre os principais artigos do Código Penal Santa Cruz - que passariam a regular os casos de asilo dos cativos -, figuravam o 109, 131, 172, 226 e 228. Com base

\footnotetext{
${ }^{31}$ Archivo Histórico de la Honorable Camara de Diputados. Coleccion Official de Leyes, Decretos, Ordenes, \& de la Republica Boliviana - años 1838. Sucre: Imprenta de Lopez, 1857. p. 31-33.

${ }^{32} \mathrm{ABNB}-\mathrm{M} 474-\mathrm{II}$ - Breve exposicion de las razones que tuvieron los que suscriben este folleto como diputados a la Asamblea Nacional de 1868, para dar su voto de aprobacion en favor del tratado de amistad, límites, navegacion, comercio y extradicion, ajustado entre los plenipotenciários de Bolivia y del Brasil en la ciudad de La Paz en 27 de Marzo de 1867. Cochabamba: Imprenta Gutierrez, 1871. p. 38. Tradução livre.
}

Revista Eletrônica da ANPHLAC, ISSN 1679-1061, n.15, p. 37-78, jul./dez. 2013. 
no artigo 109, ficou estabelecido que os escravos fugitivos deveriam ser considerados homens livres, a partir do momento em que pisassem em solo boliviano. Além disso, esse artigo previa ainda que "a extradição dos estrangeiros asilados na República da Bolívia só poderia ocorrer mediante tratado específico sobre a matéria”. O artigo 172 determinava que: "El funcionario público, dice, de cualquiera clase que entregare o hiciere entregar a otro Gobierno, o a un particular un esclavo asilado en Bolivia, o que permitiere su venta, sufrirá de uno a cuatro años de prisión" ${ }^{33}$. Além disso, o artigo 226 acabava servindo para complementar o que havia sido estipulado pelo artigo 172, ao tornar mais efetiva a punição dos que incorressem no crime de vender ou devolver escravos asilados. Entre as sanções previstas, havia uma pensada especificamente para os funcionários públicos que cometessem o crime de entregar pessoas asiladas para as autoridades de outros Estados.

De acordo com o artigo 226, do Código de 1836, os funcionários públicos passariam a estarem sujeitos à sanção de perder o cargo, se acaso incorressem em tais práticas. Além disso, ficariam proibidos de exercer quaisquer outros empregos públicos. Um dos pontos mais interessantes é o fato de que, se a pessoa entregue aos governantes estrangeiros fosse acometida de pena de morte, o cidadão boliviano acusado de restituílo seria deportado ${ }^{34}$. O Código Penal, publicado em 1845, abrandou a pena dos acusados de restituir pessoas asiladas a governos estrangeiros. Segundo o artigo 160, nos casos em que a entrega resultasse na morte da pessoa devolvida, o funcionário responsável pela entrega não seria mais deportado, mas teria que cumprir pena de cinco a dez anos de reclusão. O artigo 102 parece garantir a aquisição de alguns direitos aos cativos por prever que os "asilados en Bolivia ó traidos á ella son libres desde que pisan el territorio de la república: y los jueces están obligados á proceder, segun el código del enjuiciamiento, si reclaman su libertad" ${ }^{35}$. Essas disposições dariam as necessárias

\footnotetext{
${ }_{33}^{33}$ LIB em Cochabamba. In: AHI (410/01/05). Nota n ${ }^{\circ} 21$, de 27/12/1838.

${ }^{34}$ LIB em Lima. In: AHI (212/02/05). Ofício s/n, de 10/5/1838. Cabe lembrar que, nessa época, as repúblicas do Peru e da Bolívia encontravam-se unificadas sob a bandeira da Confederação PeruanoBoliviana (1836-1839). Por esse motivo, o Ministério dos Negócios Estrangeiros resolveu instalar sua unidade de representação no Peru. Com isso, houve a unificação da Legação Imperial do Brasil no Peru à da Bolívia, na figura de apenas um encarregado de negócios, responsável por responder pelas duas legações.

${ }^{35}$ ABNB. M 206 - Bolívia. Código Penal Boliviano. Sucre: Imprenta de Beeche y Compañía, 1845. p. 25-26; 41-42.
}

Revista Eletrônica da ANPHLAC, ISSN 1679-1061, n.15, p. 37-78, jul./dez. 2013.

http://revista.anphlac.org.br/ 
garantias, para que os asilados mantidos em cativeiro, após pisar em solo boliviano, requisitassem por vias judiciais o reconhecimento de sua nova condição legal.

Uma das primeiras aparições do princípio jurídico de solo livre ocorreu com a publicação do Código Penal, de 1830, retomado seis anos mais tarde, com a publicação do segundo Código. Ambos podem ser incluídos no repertório das dificuldades que circundavam as pretensões brasileiras de recuperar os cativos. Na América do Norte, o princípio de solo livre ou Free Soil, passou a ser adotado aproximadamente entre 18471848, para fazer oposição ao regime de trabalho escravo, no momento em que os Estados Unidos da América tomaram para si o domínio de um vasto território como resultado da guerra contra o México. Dentro das nuances de um processo político complexo, que envolveu a elaboração de leis específicas contra a escravidão, o interessante é que, muitas vezes, as fugas escravas aparecem atreladas às movimentações conhecidas como Underground Railroad, que possibilitavam a concessão de asilo territorial nos Estados em que a escravidão já tivesse sido abolida. A obra do historiador Ira Berlin (2006, p. 282-287) descreve, de modo bastante preciso, as formas de resistência encontradas pelos cativos que praticavam as fugas de longa distância. $\mathrm{O}$ autor comenta que a guerra entre nortistas negros e sulistas proprietários de escravos não se limitava apenas a palavras, uma vez que os proprietários faziam incursões nas comunidades negras do norte - assim como faziam contra os quilombos-, com a intenção de recapturar escravos fugitivos e prender pessoas livres para reduzi-las ao cativeiro.

\section{O recrudescimento das relações entre Brasil e Bolívia: o episódio dos 17}

Uma das hipóteses aventadas para o abandono do esforço de cooperação mútuo em relação à devolução dos cativos asilados foi a constante disputa pela posse dos terrenos situados em regiões limítrofes. No ano de 1837, o coronel boliviano Sebastián Ramos passou a ocupar um sítio nas imediações do que viria ser o distrito militar brasileiro de Vila Maria. As autoridades locais passaram a acompanhar as movimentações dos bolivianos, relatando ao presidente da província, que o dito Ramos havia levado toda a sua criação de gado e cavalos, para além da localidade conhecida 
como Jauru ${ }^{36}$. A criação extensiva de gado em tais áreas, bem como as recíprocas acusações de roubo, faziam parte dos cenários praticamente "esquecidos" ou abandonados por autoridades de ambos os lados.

No mesmo ano de 1837, um episódio em especial fez recrudescer o nível das tensões entre as chancelarias brasileira e boliviana: a fuga de 17 presos da cadeia pública de Cuiabá, em direção ao território boliviano. O asilo concedido aos presos motivou o envio de sucessivas notas de protesto dos governantes imperiais, que passaram a cogitar até mesmo a hipótese de validar o Tratado de Santo Ildefonso (1777), como havia sido proposto pela Missão Especial de Armaza, em 1834. Para não proceder no compromisso de devolução assumido, em 1836, a chancelaria boliviana passou a defender a tese da inexistência de atos internacionais, que tornassem obrigatória a extradição dos asilados. Dentro das relações bilaterais, os bolivianos acabaram sendo os primeiros a negar a validade do ajuste ocorrido entre os peninsulares, mesmo entendendo que sua validação traria maiores compensações territoriais.

Para compreendermos melhor o aparente paradoxo da postura assumida pelo governo boliviano, precisamos analisar mais a fundo as bases da reclamação brasileira. A chancelaria imperial baseava suas notas no conteúdo das disposições relativas ao artigo 19, do tratado de 1777, cujo teor previa que:

\begin{abstract}
em toda a fronteira será vedado, e de contrabando, o comércio entre as duas nações, ficando na sua força e vigor as leis que promulgadas por ambas coroas que disto tratam e, além desta proibição, nenhuma pessoa poderá passar do território de uma nação para o da outra por terra, nem por água, nem navegar em todo ou parte dos rios, que não forem privativos da sua nação ou comuns, com pretexto, nem motivo algum, sem tirar primeiro licença do governador ou superior do terreno, onde há de ir, ou sem que vá enviado pelo governador do seu território a solicitar algum negócio, para o qual efeito levará o seu passaporte, e os transgressores serão castigados. ${ }^{37}$
\end{abstract}

Nesse sentido, entendemos que a redação da parte extradicional do Tratado de Santo Ildefonso procurava normatizar os procedimentos a serem observados pelos

\footnotetext{
${ }^{36}$ AHI 317/04/14 - Exposição n ${ }^{\circ}$ 12, de 23/6/1859, do chefe-de-esquadra e ex-presidente da província de Mato Grosso Augusto Leverger para o chefe-de-divisão Joaquim Raimundo de Lamare. As autoridades brasileiras alegavam que, em 1837, Sebastião Ramos havia levado seu gado para além do Jauru, com a clara intenção de alegar que parte de seu gado estava naqueles campos.

37 AHI Loc. XXIII-9 - Tratado de Santo Ildefonso (1777). Instrumento original. Plenipotenciários: Francisco Inocêncio de Sousa Coutinho e conde de Floridabranca.
}

Revista Eletrônica da ANPHLAC, ISSN 1679-1061, n.15, p. 37-78, jul./dez. 2013. http://revista.anphlac.org.br/ 
agentes dos Estados, a fim de estabelecer um compromisso recíproco de preservação da propriedade escrava ou da manutenção nas respectivas possessões das populações ameríndias (VIANNA, sd, p. 70-77). Por meio das negociações, os governantes procuravam ajustar às bases de um sistema legal que respaldaria, através da reciprocidade das extradições, o direito de propriedade, no caso de passagem de cativos para domínio alheio. Para tanto, havia a previsão de que os agentes públicos de ambos os lados garantiriam a propriedade dos reclamantes nos casos de fuga, sendo essa uma das principais medidas para assegurar o título de propriedade sobre a vontade dos prófugos.

$\mathrm{Na}$ tentativa de reaver os 17 prófugos, os governantes brasileiros passaram a colocar em risco até mesmo a soberania territorial que detinham sobre diversos terrenos que vinham sendo objeto de litígio. A mudança no posicionamento dos bolivianos não chega a surpreender, pois, nessa mesma época, o encarregado de negócios, Duarte da Ponte Ribeiro, havia conseguido interceptar uma correspondência do ministro do Interior boliviano para as autoridades de Santa Cruz de la Sierra, que levantava grandes suspeitas quanto às reais intenções dos bolivianos em cumprir a promessa de restituição dos cativos, feita em 1836. A ambiguidade contida nas orientações do ministro fica clara, no momento em que pedia ao prefeito Mariano Enrique Calvo que levasse adiante a repatriação dos 17 asilados, ao passo que, recomendava às autoridades departamentais "que os enviem para Yungas, ou outro lugar distante, para que não deem desgostos" ainda maiores ${ }^{38}$. Ao tomar conhecimento do teor da correspondência, Ponte Ribeiro passou a protestar contra o que considerava uma tentativa dos bolivianos de ludibriar a boa-fé dos brasileiros. Entretanto, a resposta do ministro das Relações Exteriores da Bolívia Manuel de la Cruz Mendez às críticas não tardou. De acordo com o ministro, essa seria a forma mais adequada de cumprir as legislações republicanas que proibiam a restituição dos asilados.

Ao analisar a série de correspondências trocadas, entre os anos de 1842 e 1844, notamos um sensível endurecimento das críticas brasileiras em relação à concessão de asilo territorial aos cativos fugitivos. Em relação às críticas, o ministro das Relações Exteriores procurou defender a política assumida por seu governo, valendo-se dos

\footnotetext{
${ }^{38}$ Ministerio de Relaciones Exteriores de Bolivia - (MRE Bo) - LE - 3-R-5 - Legación del Brasil en Bolivia (1833-1871) - Recibida. Correspondência s/n., de Lima em 28/10/1837. Tradução livre. Revista Eletrônica da ANPHLAC, ISSN 1679-1061, n.15, p. 37-78, jul./dez. 2013. http://revista.anphlac.org.br/
} 
princípios filosóficos de aplicação das leis contra a escravidão e que contariam com o respaldo da legislação espanhola ${ }^{39}$. A transcrição abaixo recupera parte da argumentação de Cruz Mendez, em uma das notas dirigidas a João da Costa Rego Monteiro:

\begin{abstract}
a opinião de que o escravo que foge de seu senhor é ladrão, e como tal o governo boliviano deveria entregá-lo! Pode ser delito fugir da opressão? O homem que recobra sua liberdade primitiva deve ser considerado ladrão? De acordo com esse raciocínio, os Estados Unidos da América, as demais repúblicas da América do Sul e mesmo o Brasil é que têm sido ladrões por terem rompido as correntes que os ligavam a Inglaterra, Espanha e Portugal, e seus processos de emancipação um delito injustificável. O direito dos povos à sua independência não é menos sagrado que o dos indivíduos à sua liberdade $!^{40}$
\end{abstract}

Em ofício de 1844, João da Costa Rego Monteiro informou ao ministro dos Estrangeiros, Soares de Souza, que suas notas não vinham sendo respondidas por Cruz Mendez, e que, por isso, procurava manter conversas regulares com o presidente da República, José Ballivián. Os argumentos usados pelo agente brasileiro não apresentavam grandes variações em relação ao que vinha sendo tratado com o ministro, permanecendo a discussão a respeito da aplicação do princípio de solo livre a monopolizar as conversas. Para Rego Monteiro, as autoridades que fariam parte do poder executivo erravam, ao deixar de considerar as reais intenções dos legisladores ao instituir a validade do solo livre, que, pretensamente, não tencionava libertar os cativos foragidos que chegassem à Bolívia, mas, sim, proibir a perpetuação do tráfico negreiro. Os resultados obtidos junto a Ballivián mostraram-se mais profícuos do que os alcançados com Cruz Mendez, pois o presidente se comprometeu a pedir às Câmaras Constitucionais uma interpretação definitiva para o artigo $^{41}$.

No ofício seguinte, enviado com intervalo de um mês, Rego Monteiro lamentou a falta de resposta dos dirigentes bolivianos e levantou a hipótese de que esse silêncio

\footnotetext{
${ }^{39}$ LIB em Sucre. In: AHI (211/01/18). Nota $n^{\circ}$ 6, de 29/11/1842, anexa ao ofício $n^{\circ}$ 4, de 7/12/1842, contendo a resposta do Ministro das Relações Exteriores da República da Bolívia Manuel de la Cruz Mendez ao pedido de derrogação da circular de 30/1/1838, feito pelo Encarregado de Negócios do Brasil. Em suas considerações, o ministro boliviano apoia a negativa de seu governo ao pedido de derrogação da circular a partir da legislação espanhola do período colonial que, pelas Reais Cédulas de 20/2/1773 e 14/4/1779, proibia, com base no Direito das Gentes, a devolução dos prófugos escravos aos reclamantes, o pagamento de qualquer indenização pela concessão de asilo aos fugitivos e a liberdade que, de acordo com as cédulas, havia sido conquistada de maneira legítima.

${ }^{40}$ LIB em Sucre. In: AHI (410/01/05). Nota ${ }^{\circ} 6$, de 14/12/1842. Tradução livre.

${ }^{41}$ LIB na Bolívia. In: AHI (211/01/18). Ofício no 8, de 24/7/1844.
}

Revista Eletrônica da ANPHLAC, ISSN 1679-1061, n.15, p. 37-78, jul./dez. 2013.

http://revista.anphlac.org.br/ 
seria o resultado de uma indefinição das câmaras quanto à posição que deveria passar a guiar as ações do governo ${ }^{42}$. No mesmo ano, Rego Monteiro fez breves especulações em relação à conduta do governo boliviano, tendo em vista que:

\begin{abstract}
os escravos brasileiros seriam importantes para povoar os desertos bolivianos, limítrofes ao Império, e que a Bolívia só desistiria de seus desígnios quando o Império assinasse um tratado que reconhecesse a validade [do tratado] de 1777, o que significaria a cessão em seu favor dos terrenos de Salinas, juntamente com a permissão para navegar pelo [rio] Amazonas até o Atlântico. Em compensação, o Império [brasileiro] obteria a devolução e extradição dos escravos brasileiros. ${ }^{43}$
\end{abstract}

Procurando atuar de acordo com suas instruções, o representante imperial passou a defender o direito de propriedade dos senhores, de inúmeras formas. Em suas notas, Rego Monteiro recorreu a uma pretensa lógica contratualista, que estaria presente na relação entre senhores e escravos. Segundo o encarregado de negócios, o conjunto de direitos e garantias fundamentais dos homens - publicizados pela famosa Déclaration des Droits de l'Homme et du Citoyen, um dos libelos mais importantes da Revolução Francesa - não estariam em contradição com o ponto de vista defendido pelo Brasil, posto que o direito de propriedade deveria se sobrepor ao de liberdade. Para o agente imperial, a simples aquisição dos cativos bastaria para legitimar a ficção criada a partir da aplicação do direito positivo. Na tentativa de convencer Cruz Mendez, o negociador brasileiro passou a alegar que o contrato "tácito" entre as partes traria grandes vantagens para os africanos, tendo em vista que os mesmos se libertavam da barbárie existente no continente de origem (DAGET, 2010, p. 84) 44 $^{4}$ Além disso, a retórica utilizada por Rego Monteiro procurava apresentar uma justificativa plausível para a manutenção de seres humanos na condição de cativos, uma vez que os africanos teriam a oportunidade de partilhar os efeitos da modernidade e civilização que vinham sendo experimentados no Império do Brasil ${ }^{45}$.

\footnotetext{
${ }^{42}$ LIB na Bolívia. In: AHI (211/01/18). Ofício nº 9, de 23/8/1844.

${ }^{43}$ LIB na Bolívia. In: AHI (211/01/18). Ofício n ${ }^{\circ} 1$, de 22/6/1844.

${ }^{44}$ Em perspectiva diametralmente oposta à apresentada pelo representante brasileiro, de que a barbárie pautaria as relações sociais, econômicas e políticas internas do continente africano, Daget (2010) afirma que a "barbárie" teria sido introduzida no continente negro por obra dos brancos e do tráfico atlântico, que barbarizou milhares de africanos.

${ }^{45}$ LIB em Sucre. In: AHI (211/01/18). Nota no 7, de 3/12/1842, anexa ao ofício n ${ }^{\circ} 4$, de 7/12/1842.

Revista Eletrônica da ANPHLAC, ISSN 1679-1061, n.15, p. 37-78, jul./dez. 2013.

http://revista.anphlac.org.br/
} 
Uma das explicações para defesa do direito de propriedade encampado pelo representante brasileiro pode ser encontrada na estruturação da própria sociedade imperial, apoiada em uma hierarquia econômico-social, cuja base permanecia identificada desde o período colonial, com os agentes ligados à terra e, o cume da pirâmide social, com os indivíduos vinculados às atividades mercantis e prestamistas. Dessa forma, a defesa da ordem era um dos pressupostos básicos dentro de uma sociedade escravista, regulada por um sistema econômico que se imbricava organicamente na contínua reiteração de uma hierarquia social fortemente excludente ${ }^{46}$. Assim, a postura assumida por Rego Monteiro estava de acordo com a defesa de uma ordem privada, que assumiria o papel de regular, ao mesmo tempo, as relações econômicas e sociais, o que figurava como condição sine qua non para a concretização do processo produtivo (FRAGOSO; FLORENTINO, 2001, p. 18-19). No entanto, o agente imperial enfrentava uma controvérsia bastante delicada, uma vez que, internamente, a propriedade escrava figurava como um dos maiores consensos, ao passo que, no cenário internacional, precisava ser revalidada, a partir de critérios que não estavam baseados exclusivamente na perpetuação dos interesses privados.

Em seus protestos, Rego Monteiro insistia na tese de que os escravos que fugiam dos seus senhores deveriam ser considerados pelos bolivianos como ladrões, tendo em vista que os empreendimentos de fuga "roubariam" o capital imobilizado pelos senhores no ato de compra. $\mathrm{O}$ encarregado de negócios entendia ainda que

se o governo da Bolívia quisesse libertar aqueles escravos, isto é, aquelas propriedades brasileiras, deveria celebrar um contrato [com o Império do Brasil], pelo qual indenizasse os senhores dos mesmos, sendo essa a maneira de adquirir as cousas, serviços e direitos que tem dono, e que não estão no estado primitivo de res nullios. ${ }^{47}$

A aplicação dessa norma jurídica à situação dos cativos era considerada um equívoco pelo representante brasileiro, pois, apenas nos casos em que a propriedade não tivesse dono, ou seja, quando abandonadas em domínio alheio - porque nunca

\footnotetext{
${ }^{46}$ A necessidade de manutenção da escravidão aparece tanto nos debates parlamentares de época, quanto em inúmeras interpretações historiográficas produzidas recentemente. Entre os exemplos, citamos: BRASIL (1867, p. 182-183); DEL PRIORI; VENÂNCIO (2001, p. 254).

${ }^{47}$ LIB em Sucre. In: AHI (211/01/18). Nota n ${ }^{\circ} 7$, de 3/12/1842, anexa ao ofício ${ }^{\circ} 4$, de 7/12/1842.

Revista Eletrônica da ANPHLAC, ISSN 1679-1061, n.15, p. 37-78, jul./dez. 2013. http://revista.anphlac.org.br/
} 
pertenceram a ninguém -, ou nos casos em que o antigo dono negligenciasse a posse ou as abandonasse, é que sua aplicação poderia ser juridicamente validada.

Na literatura de história diplomática, coligimos que o abandono não se presume pela regra nemo suum jactare praesumitur, mas, sim, pela intenção do proprietário em renunciar à posse, que resultaria na cessação do poder físico sobre a propriedade, não se confundindo com o simples desamparo ou deserção (ARAUJO, 1989, p. 88-89). Por esse motivo, Rego Monteiro defendia o ponto de vista de que os casos de concessão de asilo territorial não poderiam ocorrer, senão por manifestação expressa da vontade dos proprietários dos cativos (MARTIN, 2005) ${ }^{48}$. No caso em questão, o animus seria a possibilidade de reproduzir a primeira vontade de aquisição da posse, ou seja, o fato de a posse legal não consistir em deter realmente a posse, mas em tê-la à sua livre disposição. Para tanto, o agente brasileiro buscava afirmar a tese de que a ausência do proprietário, o desamparo ou a deserção não excluiria a livre disposição dos senhores na utilização dos bens possuídos, sendo esse o pressuposto básico de aplicação do animo retinetur possessio (ARAUJO, 1989).

\begin{abstract}
É evidente que, em qualquer parte que estiver a propriedade, sempre pertence ao seu senhor, ou ela seja detida pela força, como os bens imóveis, ou levada como os móveis, ou tendo por si mesma movimento, mudem de local como as locomotivas; e, em todos esses casos, não é mister a presença física para que se acredite a propriedade, pois do contrário, ver-se-ia, seria indispensável ao possuidor de um terreno estar simultaneamente em todos os cantos dele, ou que sempre tivesse as mãos sobre a cousa. Conseguintemente, segundo a Lei do direito, a cousa possuída por ente racional, ainda que dele esteja separada, deve considerar-se pela sua relação legal com a vontade, como se estivesse sempre imediatamente unida a sua pessoa ${ }^{49}$.
\end{abstract}

Dessa forma, Rego Monteiro pautava-se na certeza de que os pressupostos jurídicos que legitimavam a concessão de asilo territorial aos fugitivos asilados seriam ilegais, uma vez que não havia registro de casos de renúncia por parte dos senhores da província de Mato Grosso. Esse fato, por si só, já seria suficiente para desqualificar a

\footnotetext{
${ }^{48} \mathrm{O}$ trabalho de Martin (2005) esquadrinha o surgimento do conceito moderno de propriedade em diferentes sociedades e seus desdobramentos políticos, jurídicos, econômicos, sociais e culturais etc. Nesse sentido, o autor analisa as contribuições de inúmeros filósofos e pensadores que se debruçaram sobre o tema e conclui que a constituição da propriedade teve inúmeras fontes e contou com graus diferenciados de legitimidade. No que diz respeito à lógica do direito de propriedade passar a ser aplicado a seres humanos, ou seja, no que tange à experiência de imposição do cativeiro, comumente evoca-se o direito de conquista para justificar propriedades injustificáveis.

${ }^{49}$ LIB em Sucre. In: AHI (211/01/18). Nota n ${ }^{\circ} 7$, de 3/12/1842, anexa ao Ofício ${ }^{\circ}$ 4, de 7/12/1842.
}

Revista Eletrônica da ANPHLAC, ISSN 1679-1061, n.15, p. 37-78, jul./dez. 2013.

http://revista.anphlac.org.br/ 
aplicação do princípio de res nullios, reivindicado pelos negociadores bolivianos (VAZQUEZ-MACHICADO, 1990, p. 162) ${ }^{50}$. Por seu turno, o representante brasileiro defendia a proposta de que o ato de compra dos cativos passasse a ser interpretado pelo governo boliviano como uma espécie de contratação de serviços pessoais por tempo indeterminado, o que estaria de acordo com a categoria jurídica conhecida como el albala, comumente usada nas legislações ibéricas, com o intuito de garantir o gozo de um direito ou de uma graça concedida pelo rei (BENITO, 2002, p. 98-100) ${ }^{51}$. Essa norma faria parte do conjunto de leis e regras que garantiriam, ainda nos tempos coloniais, o título legítimo de posse reconhecido pelas nações na esfera internacional, por representar o capital empregado na compra da propriedade ${ }^{52}$.

\section{Entre propriedade e liberdade: em embate diplomático à luz da filosofia}

À medida que o agente brasileiro endurecia as críticas em relação à prática que vinha sendo adotada pelo governo boliviano, o ministro Cruz Mendez se esforçava para rebater o vasto repertório de Rego Monteiro. De um lado, percebemos que o governo boliviano desejava assegurar o direito de navegar livremente os rios sob jurisdição parcial do Brasil e, de outro, o Império brasileiro pretendia ajustar um tratado de fronteiras e extradição que encerrasse as hostilidades recíprocas. Entretanto, o ministro refutava as reclamações do encarregado de negócios, a partir de um bem elaborado questionamento acerca do tipo de contrato que vigoraria entre senhores e escravos. Para o ministro, o contrato deveria estar baseado no "consentimento e utilidade recíproca entre as partes”, o que, desde o início do processo de constituição da propriedade, não poderia ser verificado, cumprindo observar que bem conhecido era o processo de transformação de homens livres em cativos no continente africano.

\footnotetext{
${ }^{50} \mathrm{O}$ autor ensina que o termo res nullios é uma expressão latina, cujo significado relaciona-se à ideia de algo que não pertence a ninguém, ou seja, àquilo que não é propriedade de ninguém. No entanto, Vazquez-Machicado (1990) faz a ressalva de que a terra nunca poderia ser considerada como uma propriedade sem dono. Para regular esses casos, havia o res nullios fit primi occupantis, que se refere a tudo aquilo que é não de ninguém passar a pertencer ao primeiro que efetivamente a ocupasse. De acordo esse princípio jurídico, os bens passíveis de serem adquiridos seriam os tesouros ocultos, os bens móveis abandonados e os animais que são objeto de caça e pesca.

${ }^{51}$ Ao pesquisar os possíveis significados do termo albalá, localizamos uma definição distinta da usada nas fontes coligidas. No trecho da obra selecionada, a expressão parece denotar uma espécie de autorização para comerciar vinho na região de Toledo, por meio do pagamento de um imposto.

${ }^{52}$ LIB em Sucre. In: AHI (211/01/18). Nota n ${ }^{\circ}$, de 3/12/1842, anexa ao Ofício n ${ }^{\circ} 4$, de 7/12/1842.

Revista Eletrônica da ANPHLAC, ISSN 1679-1061, n.15, p. 37-78, jul./dez. 2013.

http://revista.anphlac.org.br/
} 
Na defesa da posição de seu governo, Cruz Mendez passou discorrer sobre a barbárie com que os negros eram arrancados de suas terras na África, transportados em condições desumanas, nas embarcações que se prestavam ao "tráfico de carne humana". O ministro seguia sua linha de raciocínio, dizendo que, posteriormente, os africanos eram vendidos como mercadorias por norte-americanos, demais repúblicas sulamericanas e pelo próprio Brasil ${ }^{53}$. Cruz Mendez rebateu a reclamação brasileira, ao dizer que o governo boliviano não poderia reconhecer a validade jurídica de uma propriedade baseada estritamente na força, primeiro e único título a regular seu funcionamento ${ }^{54}$. Para embasar as negativas de extradição do governo boliviano, acreditamos que o ministro tenha se apoiado, em larga medida, nos escritos do filósofo Jean-Jacques Rousseau, pois, ao justificar o asilo territorial que vinha sendo concedido aos cativos, o ministro apontava as contradições da relação entre escravidão e direito natural, que, na obra daquele pensador, aparece da seguinte forma:

renunciar à liberdade é renunciar à qualidade de homem, aos direitos da humanidade e até aos próprios deveres. Não há recompensa possível para quem a tudo renuncia. Tal renúncia não se compadece com a natureza do homem, e destituir-se voluntariamente de toda e qualquer liberdade equivale a excluir a moralidade de suas ações. (ROUSSEAU, 1978, p. 28)

Durante o período em que Cruz Mendez ocupou a titularidade da chancelaria boliviana, o governo passou a enfrentar os protestos brasileiros, a partir da adoção de uma retórica que desacreditava as bases legais de um contrato que obrigaria apenas uma das partes contratantes a renunciar à própria liberdade primitiva. Do ponto de vista filosófico, o livre exercício da liberdade pessoal figurava entre os axiomas fundamentais do conjunto de direitos conhecidos como Direitos Naturais dos Homens, sendo esse uma das bases para a existência do Direito das Gentes. Dada a flagrante contravenção desse tipo de contrato com os princípios mais básicos da dignidade humana, o ministro seguia questionando sua perfeição ${ }^{55}$. Em um dos muitos apontamentos acerca da justiça das queixas brasileiras, o ministro reconheceu a existência, em meio ao Direito das Gentes, de um princípio que regularia a aplicação das leis internacionais nos casos de

\footnotetext{
${ }^{53}$ LIB em Sucre. In: AHI (410/01/05). Nota $\mathrm{n}^{\circ}$ 6, de 14/12/1842.

${ }_{55}^{54}$ LIB em Sucre. In: AHI (211/01/18). Nota $n^{\circ} 1$, de 14/12/1842, anexa ao ofício n ${ }^{\circ} 5$, de 29/12/1842.

${ }^{55}$ LIB em Sucre. In: AHI (211/01/18). Nota $n^{\circ} 1$, de 14/12/1842, anexa ao ofício $n^{\circ}$ 5, de 29/12/1842. Revista Eletrônica da ANPHLAC, ISSN 1679-1061, n.15, p. 37-78, jul./dez. 2013. http://revista.anphlac.org.br/
} 
disputa entre normas e/ou convenções de dois Estados litigantes. No caso em questão, o Estado reclamante deveria adotar o rigor das leis do Estado onde o crime supostamente tivesse sido cometido, ou seja, nesse caso, a preferência deveria ser dada à legislação da Bolívia, onde se controvertia o rigor da pena, por não haver o reconhecimento do cativo como propriedade, quando em solo boliviano.

Cruz Mendez seguiu explicando que, no território boliviano, a legislação consagrava que os homens não eram considerados coisa, já que haviam sido feitos à imagem e semelhança do Criador. Para o ministro, a instituição escravista no Império do Brasil pressupunha a privação da razão e da liberdade, marcas indeléveis da condição de humanidade que distinguiria os homens dos demais animais. Nesse ponto, a obra de David B. Davis (2001) apresenta-se como referência fundamental para compreendermos os debates que polarizavam as atenções dos negociadores ${ }^{56}$. Esse autor demonstra que as justificativas que legitimavam o poder de um homem sobre outro vinham perdendo espaço desde a Antiguidade Clássica, e que a imposição da força pelos senhores tornou o "contrato tácito" entre senhores e escravos uma ficção sem sentido nos terrenos do direito e da história. A antiguidade e o costume - respaldados pela tradição do direito positivo - já não seriam elementos suficientes para garantir indefinidamente a perpetuação da instituição escravista, abrindo espaço, no plano mental dos subjugados, para a legitimação das movimentações de fuga e rebelião (DAVIS, 2001, p. 139).

A sequência das negociações revelou que Cruz Mendez havia formulado uma longa nota em resposta aos pedidos feitos por Rego Monteiro. Em sua correspondência, o ministro expôs o entendimento do governo boliviano acerca da situação dos cativos brasileiros, que não eram e nem poderiam ser objeto de indenização pecuniária por parte do seu governo, uma vez que o direito de propriedade escrava não encontraria correlativo de aplicação nas matérias legais de sua nação. De acordo com o ministro, o fato de os governantes brasileiros considerarem o cativo fugitivo como ladrão estaria em contradição "com os axiomas fundamentais da justiça e do direito natural" 57 . No repertório de Cruz Mendez, a controvérsia sobre a restituição dos cativos passou pela reafirmação das matérias contidas nas cartas constitucionais de 1826, 1831, 1834, 1839

\footnotetext{
${ }^{56} \mathrm{O}$ autor abrilhanta a sua obra ao analisar as justificativas filosóficas em diferentes momentos históricos para a existência e utilização da instituição escravista por diversas sociedades.

${ }^{57}$ LIB em Sucre. In: AHI (211/01/18). Nota no 1, de 14/12/1842, anexa ao ofício n ${ }^{\circ} 5$, de 29/12/1842.

Revista Eletrônica da ANPHLAC, ISSN 1679-1061, n.15, p. 37-78, jul./dez. 2013.

http://revista.anphlac.org.br/
} 
e dos códigos penais de 1830 e 1836, que proibiam, sucessivamente, a extradição, devolução ou repatriação dos estrangeiros que pisassem o solo da nação.

A disputa do encarregado de negócios do Brasil com Cruz Mendez pode ser mais bem compreendida, quando recuperamos a noção de liberdade utilizada por alguns filósofos do século XVIII. O historiador David B. Davis (2001) apresenta os argumentos de um dos filósofos que mais contribuiu para o fortalecimento do pensamento antiescravocrata: Montesquieu. Esse foi um dos filósofos que submeteram a existência e funcionamento da instituição escravista às ferramentas críticas do Iluminismo. Na obra $O$ espírito das leis, Montesquieu (2000) considerou a existência do escravismo de acordo com os princípios universais - de uso costumeiro e título de propriedade -, que serviriam para legitimar sua perpetuação, mas que, ao mesmo tempo, encontravam-se em franca oposição com o conjunto de direitos naturais dos homens. Em seus trabalhos, o autor procura destacar as consequências negativas da manutenção do regime de trabalho escravo e, por esse motivo, suas ideias foram retomadas pelos movimentos antiescravistas posteriores, que tiveram nos escritos de Rousseau uma de suas expressões mais radicais (DAVIS, 2001, p. 448).

Rousseau (1978) defendia a tese de que, no plano moral, a força não poderia figurar como instrumento de legitimação dos contratos de autovenda, que, de maneira geral, garantiam a reprodução da instituição escravista em diversas sociedades. Além disso, o autor ajudou a difundir a máxima de que "todo homem nascia livre", e que o emprego da força não poderia constituir-se como base de um direito legítimo ou perfeito, por contrariar as lógicas pautadas na razão e a própria condição de humanidade das pessoas escravizadas. Em suas reflexões, Rousseau (1978, p. 22-28) considera a escravidão como uma aberração legitimada pelo uso ou costume e conclui que escravidão e direito excluíam-se mutuamente. Desse modo, as argumentações de Rego Monteiro encontravam na obra de Rousseau uma base filosófica e moral, que obstava sua validação pela dificuldade de ser refutada.

Ao retomar o plano das disputas diplomáticas, notamos que as reiteradas notas de protesto do representante brasileiro motivaram negativas cada vez mais duras por parte dos governantes bolivianos. Nessa época, início da década de 1840, um episódio contribuiu significativamente para aumentar as tensões entre Brasil e Bolívia: o acesso de Rego Monteiro a uma correspondência interna entre alguns órgãos da administração Revista Eletrônica da ANPHLAC, ISSN 1679-1061, n.15, p. 37-78, jul./dez. 2013. http://revista.anphlac.org.br/ 
pública do governo boliviano. O agente imperial concluiu que Cruz Mendez adotava uma linha de raciocínio nas negociações externas, ao passo que dava instruções em sentido contrário aos prefeitos dos departamientos limítrofes ao Império brasileiro. $\mathrm{O}$ teor das orientações enviadas pelo ministro ao prefeito do departamiento de Santa Cruz de la Sierra basicamente revelam quais procedimentos deveriam ser adotados no caso de escravos oriundos da província de Mato Grosso. Na comunicação interceptada por Rego Monteiro, em 1843, Cruz Mendez ordenou que o prefeito evitasse deixar prófugos escravos em regiões de fronteira, devendo conduzi-los, assim que possível, para o interior do território ${ }^{58}$.

A resposta de Cruz Mendez ao protesto de Rego Monteiro pode ser encontrada em uma nota recebida pelo agente brasileiro, aproximadamente quatro meses depois que teve acesso ao expediente interno do governo boliviano. Na defesa dos interesses de seu governo, Cruz Mendez alegou que havia dado ordens expressas para que não fossem incitadas movimentações de fuga internacional pelas autoridades bolivianas, e que, caso fosse comprovada a participação de algum servidor público, esse seria castigado com a severidade das leis ${ }^{59}$. No entanto, o ministro rebateu as acusações do encarregado de negócios, ao dizer que sua postura apenas refletia o entendimento de que a devolução dos cativos asilados implicaria no ato de reescravização, uma vez que os mesmos já teriam conquistado a liberdade pessoal, pelo fato de ter cruzado as linhas de fronteira internacional e pisado em solo boliviano ${ }^{60}$.

\section{Os processos de negociação entre as décadas de 1840 e 1860}

No ano de 1847, houve a substituição de João da Costa Rego Monteiro por Antônio José Lisboa no posto de encarregado de negócios do Brasil na Bolívia (CAMPOS, 1913, p. 24-26) ${ }^{61}$. Uma análise da correspondência da legação revelou uma

\footnotetext{
${ }^{58}$ AHI (410/01/05). Nota $\mathrm{n}^{\circ}$ 9, de Sucre em 13/10/1843, contendo as instruções do ministro Cruz Mendez ao prefeito do departamiento de Santa Cruz de la Sierra.

${ }^{59}$ LIB em La Paz. In: AHI (410/01/05). Nota no 26, de 5/2/1844; ABNB. M206 - BOLÍVIA. Código Penal Boliviano (1845). Sucre: Imprenta de Beeche y Compañia, 1845. p. 39-40.

${ }^{60}$ LIB em Cochabamba. In: AHI (410/01/05). Nota ${ }^{\circ} 21$, de 27/12/1838.

${ }^{61}$ Gostaríamos de esclarecer que a relação dos representantes diplomáticos do Império do Brasil na Bolívia nem sempre está em consonância com as indicações de Raul Adalberto de Campos (1913). No caso da legação boliviana, as fontes primárias indicam o mês de março de 1847 como a provável data de assunção de Antônio José Lisboa, mas, para Campos, o período de Lisboa compreende de 11/10/1844 a 24/2/1851.
}

Revista Eletrônica da ANPHLAC, ISSN 1679-1061, n.15, p. 37-78, jul./dez. 2013.

http://revista.anphlac.org.br/ 
sensível mudança no perfil das reclamações imperiais, que passaram a refletir quase exclusivamente as preocupações desse representante, com a preservação do status quo territorial e com o direito do Império de Brasil ser a única nação autorizada a conceder a navegação dos rios da bacia do Amazonas. Durante o período que Lisboa esteve à frente da legação brasileira, as reclamações sobre o acolhimento dado aos cativos e os pedidos de repatriação praticamente desapareceram das pautas de negociação, modificando radicalmente a visibilidade que Rego Monteiro dava à questão ${ }^{62}$. Por não haver instruções do Ministério dos Estrangeiros para o encarregado de negócios, Antônio J. Lisboa, não podemos dizer se a postura do representante estaria de acordo com as metas preconizadas pelo ministério ou se, pelo contrário, seria fruto de um entendimento pessoal do novo encarregado de negócios.

O que parece certo é que, entre as décadas de 1850 e 1860, ocorreu uma sensível diminuição das reclamações dos representantes brasileiros em relação ao asilo territorial que vinha sendo concedido aos escravos fugitivos em território boliviano. Sobre a mudança de atitude, não conseguimos precisar se houve uma drástica diminuição das movimentações internacionais de fuga dos cativos, se os encarregados de negócios, que sucederam João da Costa Rego Monteiro na legação, resolveram adotar postura diversa da que vinha sendo até então praticada ou se o ministério forneceu algum tipo de orientação nesse sentido. Nessa perspectiva, a possibilidade de diminuição das fugas internacionais aparece como uma das hipóteses menos prováveis, uma vez que pouca coisa vinha sendo feita em ambos os lados, para coibir a perpetuação de tais movimentações. A questão de fundo que ora se apresenta é a possibilidade de a mudança de postura do ministério ser fruto de uma reorientação partidária, capitaneada por conservadores ou liberais.

Nesse sentido, a titularidade da pasta dos Estrangeiros estava entregue a Paulino José Soares de Souza, desde 1849, ou seja, o ministério era comandado por um dos membros mais eminentes do Partido Conservador. Esse fato serve como ponto de partida para fazermos uma breve reflexão acerca das vinculações partidárias dos ministros dos negócios estrangeiros e da importância - ou não - dos partidos políticos

\footnotetext{
${ }^{62}$ Gostaríamos de esclarecer que embasamos nossas afirmações exclusivamente na análise dos assuntos tratados pelo representante em seus ofícios. Entre as fontes coligidas, figura: LIB em La Paz. In: AHI (211/01/18). Ofício n 2, de 30/1/1847.

Revista Eletrônica da ANPHLAC, ISSN 1679-1061, n.15, p. 37-78, jul./dez. 2013. http://revista.anphlac.org.br/
} 
como formuladores de diretrizes em matéria de política exterior. A historiadora Gabriela Nunes Ferreira (2006) desenvolveu uma linha de raciocínio semelhante, ao analisar a mudança de posicionamento político do Império do Brasil na região do Prata, durante a gestão do próprio Soares de Souza. A autora coloca uma questão bastante pertinente, que deve necessariamente permear os horizontes de preocupação dos investigadores que analisam o planejamento e execução das metas formuladas pela Secretaria e Ministério de Estado dos Negócios Estrangeiros, qual seja, a possibilidade de se pensar "na existência de uma 'política externa conservadora' e de uma 'política externa liberal"” (FERREIRA, 2006, p. 137. Grifos da autora).

No campo da política interna, Ferreira (2006) acredita ser possível distinguir alguns temas que contribuíram para delinear as identidades partidárias (MATTOS, 1987). Para tanto, a autora cita as palavras de Oliveira Torres, que ressalta a agenda conflitante dos partidos em relação a dois temas: a existência e atuação do Poder Moderador e o binômio formado pela centralização/descentralização do poder (FERREIRA, 2006, p. 138) ${ }^{63}$. No terreno da política exterior, no entanto, a autora considera ser mais difícil distinguir grandes diferenças ideológicas entre os dois agrupamentos. Para reforçar seu ponto de vista, Ferreira (2006) cita algumas considerações feitas por Amado Cervo (1981), que procura ressaltar a possibilidade de a política externa ter sido antes um instrumento de conciliação partidária do que um elemento de desunião entre os mesmos. A autora cita ainda as proeminentes contribuições de Francisco Iglésias (1985), Ubiratan Macedo (1979), Ilmar de Mattos (1987) e José Murilo de Carvalho (2003), mas, por não fazer parte do ponto fulcral de nosso trabalho, optamos por não discorrer sobre o modo como os governantes conduziram as questões relacionadas ao Prata.

A tarefa que ora se nos apresenta é de extrema importância, pois cria a oportunidade de verificarmos, dentro do conjunto de ações do ministério, se as vinculações partidárias do titular da pasta interferiam de alguma maneira na formulação das metas a serem alcançadas pelos representantes brasileiros. Para tanto, selecionamos alguns momentos-chave da conturbada relação de Brasil e Bolívia, especialmente aqueles em que recrudesciam as tensões diplomáticas causadas pelo acolhimento que as

\footnotetext{
${ }^{63}$ Uma obra sobre as disputas interpartidárias que poderia ter sido incluída é: MELO (1979).

Revista Eletrônica da ANPHLAC, ISSN 1679-1061, n.15, p. 37-78, jul./dez. 2013. http://revista.anphlac.org.br/
} 
autoridades bolivianas vinham dando aos cativos provenientes do Brasil. Entre os anos de 1836 e 1838, quando do episódio em que o governo boliviano se comprometeu a restituir os cativos que buscassem asilo em seu território, não foi possível precisar a filiação partidária dos sete ministros que ocuparam a pasta dos Estrangeiros. No entanto, no período compreendido entre 1840 e 1843, o ministério foi chefiado pelo conservador Aureliano de Souza e Oliveira Coutinho, que procurou manter o mesmo ânimo de seus antecessores no tocante à necessidade de extradição dos cativos que procuravam asilo na Bolívia.

Em 1843, Oliveira Coutinho deu lugar a Honório Hermeto Carneiro Leão, político conservador que permaneceu no ministério por aproximadamente quatro meses. Em junho de 1843, Paulino José Soares de Souza ocupou a titularidade da pasta pela primeira vez, tendo acedido ao mesmo cargo em 1849 e por lá permanecido durante quatro anos. Até aqui, há de ser ressaltada a existência de breves interregnos, em que o ministério foi ocupado por membros do Partido Liberal. Em agosto de 1859, Duarte da Ponte Ribeiro redigiu orientações no sentido de mostrar a impertinência de o ministério continuar exigindo a devolução dos cativos. O detalhe é que o experiente diplomata cumpriu sua tarefa poucos dias depois do liberal João Lins Vieira Cansansão de Sinimbu ter ocupado a titularidade da pasta dos Estrangeiros, ou seja, provavelmente o ministro não teve qualquer interferência na condução do trabalho de Ponte Ribeiro. Embora julguemos procedente a possibilidade de interferência da vinculação partidária dos ministros, no tocante à atuação do Ministério dos Estrangeiros, as poucas informações que reunimos não permitem que façamos maiores considerações acerca da questão, no que diz respeito à atuação da chancelaria brasileira no trato das tentativas de repatriação dos cativos asilados na Bolívia.

Uma análise pormenorizada das mudanças nas conjunturas internacionais, entre as décadas de 1850 e 1860, certamente ajudam na compreensão acerca das causas da sensível diminuição dos pedidos de extradição dos cativos asilados na Bolívia. É ponto pacífico no debate historiográfico em relação à atuação da diplomacia brasileira, que a assunção de Paulino José Soares de Sousa à frente da pasta dos Estrangeiros, em 1849, deu margem a uma reorientação das pautas de interesse da política externa brasileira, que passaram a ser defendidas de modo claro (SANTOS, 2002, p. 67). Na primeira metade da década de 1850, o ministério, enfim, superou a fase de modificações Revista Eletrônica da ANPHLAC, ISSN 1679-1061, n.15, p. 37-78, jul./dez. 2013. http://revista.anphlac.org.br/ 
constantes de atitude em relação aos principais temas de sua agenda, a partir do momento em que definiu as doutrinas que deveriam balizar as negociações diplomáticas até o final do período imperial. Foi nesse momento, que o ministério desencadeou uma ofensiva diplomática, enviando Ponte Ribeiro ao Peru e à Bolívia e Miguel Maria Lisboa (barão de Japurá) à Colômbia, Venezuela e ao Equador, com o intuito de negociar tratados de limites baseados no princípio do uti possidetis ${ }^{64}$. No relatório do Ministério dos Estrangeiros, submetido em 1853, à apreciação da Assembleia Geral Legislativa, Soares de Souza justificava a utilização do princípio de uti possidetis, a partir de um sentido eminentemente defensivo, uma vez que seria mais interessante garantir uma fronteira que se afigurava máxima, em virtude da percepção de que a população brasileira refluía para o litoral (SANTOS, 2002, p. 67).

Nas instruções de 1851, do ministro dos Estrangeiros, Soares de Souza, a Ponte Ribeiro, quando foi enviado em Missão Especial para o Peru e a Bolívia, o negociador brasileiro foi orientado a apenas apontar as questões com a Bolívia, não insistindo em nenhuma delas, por causa da possibilidade de haver uma guerra contra Juan Manuel de Rosas (LYNCH, 2001, p. 660-663) ${ }^{65}$. Além disso, havia a recomendação para que Ponte Ribeiro insistisse no reconhecimento do princípio de uti possidetis para ajustar as linhas de fronteira. Em meio às instruções, surgiu, na parte extradicional, o primeiro indício de que o ministério abandonaria os pedidos de extradição dos cativos que praticassem as fugas internacionais, pois o negociador "ficava autorizado a demover quaisquer entraves ao acerto do tratado [de fronteiras] que julgasse de pouco valor para o Império". Acreditamos que essa parte esteja relacionada com os pedidos de extradição dos cativos $^{66}$.

Uma das justificativas possíveis para a mudança de orientação do ministério em relação à questão do asilo seria a crença do ministro Soares de Souza, de que as nações limítrofes conspiravam contra o Brasil, com a intenção de obter uma saída para o

\footnotetext{
${ }^{64}$ De acordo com as respectivas indexações no arquivo do Itamaraty/RJ, a série documental referente às missões especiais Duarte da Ponte Ribeiro e do barão de Japurá nas repúblicas do Pacífico compreendem, respectivamente, os maços 271/04/16 até 271/04/18 e 271/04/19 até 271/04/25.

${ }^{65}$ Diversos autores e também a pesquisa documental apontam o descontentamento do Império brasileiro com o fechamento da navegação fluvial do estuário do Prata, como motivo para a ação dos brasileiros na região.

${ }_{66}$ AHI 317/04/13 - Instruções expedidas pelo Ministério dos Negócios Estrangeiros ao Enviado Extraordinário e Ministro Plenipotenciário na Bolívia e no Peru Duarte da Ponte Ribeiro, em 1/3/1851.
}

Revista Eletrônica da ANPHLAC, ISSN 1679-1061, n.15, p. 37-78, jul./dez. 2013.

http://revista.anphlac.org.br/ 
Atlântico, contando, para isso, com o apoio de potências extracontinentais ${ }^{67}$. Na outra ponta da ofensiva diplomática, o envio de Lisboa foi pensado como uma tentativa de afastar possíveis apoios da Colômbia, Venezuela e Equador ao caudilhismo argentino (SVAMPA, 1998, p. 52), em uma guerra que, naquele momento, era dada como certa pelo Brasil (SANTOS, 2002, p. 75). O ministro dos Estrangeiros ainda acenou com a possibilidade de que a missão desempenhada por Lisboa utilizasse as concessões de navegação dos rios para aumentar o poder de barganha nos ajustes de fronteira ${ }^{68}$.

A possibilidade de guerra entre o Brasil e Buenos Aires fez com que o ministério buscasse afastar quaisquer possibilidades de dissensão com as demais nações sulamericanas, modificando sobremaneira o curso das negociações e a importância dos itens em pauta. Nesse momento, a navegação fluvial era considerada um ponto central para a assinatura de acordos internacionais que afastassem a possibilidade de desavença, uma vez que, como vimos, o Brasil adotava uma postura diferenciada nos subsistemas platino e andino. O governo brasileiro pretendia assegurar o direito à livre-navegação na Bacia do Prata, ao passo que refutava as tentativas de abertura do Amazonas, região em que cidadãos norte-americanos solicitavam autorização para navegar os rios desde 1826. Esse foi o ponto de partida de uma longa série de negativas a tal pretensão. Em relação à postura do Império do Brasil, Luís C. Villafañe Santos (2002, p. 68) lança mão da hipótese de que a navegação dos rios em regiões longínquas e desabitadas poderia representar um risco à soberania nacional.

As nações do Pacífico sul, com exceção do Chile, ribeirinhos superiores da Bacia Amazônica, vinham solicitando a concessão da navegabilidade dos rios, e os governantes brasileiros sistematicamente a negavam, desde a década de 1820. Havia o temor de que o acesso redundasse na ocupação dos terrenos, uma vez que o próprio Brasil validava o princípio de uti possidetis em eventuais disputas territoriais. Em vista dos interesses divergentes no Prata e no Amazonas, o Império do Brasil tinha dificuldades para estabelecer uma posição coerente sobre o tema. A navegação no Prata era um objetivo perseguido pelos agentes imperiais, por causa das facilidades de comunicação com as províncias de Mato Grosso, oeste do Paraná e São Paulo, enquanto

\footnotetext{
${ }^{67}$ AHI 271/04/19 - Instruções expedidas pelo Ministério dos Negócios Estrangeiros ao barão de Japurá, para o desempenho de sua Missão Especial nas Repúblicas do Pacífico, entre os anos de 1852-1855.

${ }^{68}$ AHI 271/04/19 - Instruções expedidas pelo Ministério dos Negócios Estrangeiros ao barão de Japurá, para o desempenho de sua Missão Especial nas Repúblicas do Pacífico, entre os anos de 1852-1855.
}

Revista Eletrônica da ANPHLAC, ISSN 1679-1061, n.15, p. 37-78, jul./dez. 2013. 
a recusa de abrir o Amazonas era uma questão estratégica. Havia uma clara contradição entre o tratamento dado pelo Império brasileiro aos pedidos de navegação pelo Amazonas e as tentativas de abertura do rio da Prata, fechado por Rosas, em 1835.

No final da década de 1850, mais precisamente em 1859, o Ministério dos Estrangeiros cogitava a possibilidade de enviar um novo representante para a Bolívia, com a incumbência de negociar um tratado que regulamentasse prioritariamente as linhas de fronteira internacional e a questão da navegabilidade dos rios. $\mathrm{O}$ escolhido para chefiar a Missão Especial de 1860 foi João da Costa Rego Monteiro, profundo conhecedor das dificuldades de afirmação das metas brasileiras nos processos de negociação com a Bolívia. O envio desse representante sinaliza claramente a intenção do governo imperial de negociar um tratado de limites, extradição e navegação fluvial que, naquele momento, era considerado pelo Ministério dos Estrangeiros de grande urgência ${ }^{69}$. Ao atuar nos bastidores da formulação das metas brasileiras, Duarte da Ponte Ribeiro posicionou-se contra a incorporação de reivindicações que "em nada contribuiriam para o engrandecimento nacional". Em suas ponderações, Ponte Ribeiro lembrava que nunca tinha havido sequer um caso de extradição dos cativos asilados na Bolívia, apesar das constantes reclamações brasileiras, que se arrastavam por quase três décadas.

O ponto de vista defendido por Ponte Ribeiro, de que "nunca tinha havido sequer um caso de extradição dos cativos asilados na Bolívia" ${ }^{\text {" }}$, acabou servindo para consolidar uma importante modificação na postura imperial: a desistência de se obter a repatriação dos fugitivos. As negociações bilaterais, que passaram a ocorrer a partir de 1860, são um reflexo da perda de prioridade que a pauta relativa à necessidade de extradição dos cativos asilados passou a ter dentro do Ministério dos Estrangeiros. Essa, digamos, "armadilha documental", deixada por Ponte Ribeiro, serviu como uma das principais orientações para a formulação da dissertação de mestrado que apresentamos há poucos anos (CALDEIRA, 2007, p. 52). Como contraponto à enunciação de Ponte Ribeiro, recordamos o caso da devolução dos três cativos para o brasileiro Mariano

\footnotetext{
${ }^{69}$ AHI 317/04/15 - Instruções expedidas pelo Ministério dos Negócios Estrangeiros ao Ministro Residente João da Costa Rego Monteiro, em 12/3/1860. A observação em relação aos tratados é do ministro dos negócios estrangeiros, João Lins Vieira Cansanção do Sinimbu.

70 AHI 317/04/15 - Minuta de projeto de tratado dirigida ao Ministério dos Negócios Estrangeiros por Duarte da Ponte Ribeiro, em 25/9/1859.

Revista Eletrônica da ANPHLAC, ISSN 1679-1061, n.15, p. 37-78, jul./dez. 2013. http://revista.anphlac.org.br/
} 
Apinagé, em $1837^{71}$, que ajudou a desmontar a tese apresentada por Ponte Ribeiro, em 1859, por ocasião da formulação da minuta de projeto de tratado, que deveria passar a orientar a postura brasileira em relação às negociações com a Bolívia.

A aparente "imprecisão" de Ponte Ribeiro talvez possa ser explicada pela profunda mudança das conjunturas internacionais que vinham sendo experimentadas pelas nações sul-americanas, no decorrer da década de 1860. Ao lançarmos um olhar para a situação específica do Império do Brasil, notamos que os melhores quadros da diplomacia imperial eram unânimes em apontar a urgência de que o Brasil cortasse o mais rapidamente possível quaisquer possibilidades de dissensão com as nações limítrofes, especialmente no que tange aos assuntos de demarcação das linhas de fronteira (SANTOS, 2002, p. 99). A causa da repatriação dos cativos asilados também pode ter perdido a importância que chegou a ter nas décadas anteriores, por causa dos ínfimos resultados alcançados em relação aos esforços que os governantes brasileiros vinham fazendo há exatas três décadas. Essas breves conjecturas parecem ser suficientes para explicar a postura que passou a ser defendida por Ponte Ribeiro. Afinal, fica difícil supor que o encarregado de negócios do Brasil, na época, não tivesse tomado conhecimento da devolução dos três escravos asilados.

Pela clara distinção entre os interesses centrais - identificados como nacionais e as pautas de reivindicação provinciais, entendemos que as formulações de Ponte Ribeiro possam ser tomadas como uma rara oportunidade para atestarmos a discrepância entre as prioridades nas pautas das elites políticas centrais e/ou provinciais/locais. Por esse motivo, os escritos de Ponte Ribeiro acabam servindo para embasar uma das hipóteses inicialmente levantadas por este trabalho, qual seja, a de que, no âmbito das negociações diplomáticas do Brasil com a República da Bolívia, a defesa da propriedade escrava foi deixando paulatinamente de figurar entre as prioridades do poder central, a partir da década de $1850^{72}$. A versão final das instruções de Rego Monteiro para o desempenho da Missão Especial, em 1860, acaba confirmando as sugestões formuladas por Ponte Ribeiro, com o ministro Cansanção de Sinimbu,

\footnotetext{
${ }^{71}$ UAGRM - F/MMC19-L2 - Carpeta 19-Legajo 2 - Doc. 1837-1879 - Cartas de Provincias del Brasil enviadas al Gobierno Boliviano. Carta de Santa Cruz de la Sierra, enviada no dia 6/3/1837, redigida pelo comissário Mariano Ribeiro da Silva Apinagé, sem indicação precisa do destinatário.

${ }^{72} \mathrm{O}$ conteúdo das instruções, especialmente a partir da formulação de Duarte da Ponte Ribeiro da minuta de 1859, elucida quaisquer dúvidas a respeito da prioridade que deveria ser dada pelo Ministério dos Negócios Estrangeiros no ajuste das linhas de fronteira em detrimento das demais pautas de interesse.
}

Revista Eletrônica da ANPHLAC, ISSN 1679-1061, n.15, p. 37-78, jul./dez. 2013.

http://revista.anphlac.org.br/ 
autorizando o negociador brasileiro a "desistir inteiramente da exigência de devolução dos escravos fugitivos, se julgasse que tal desígnio iria prejudicar o interesse principal das negociações: o acerto das fronteiras"73. Desse modo, a análise das negociações diplomáticas do Brasil com a Bolívia revela o momento exato em que a defesa do direito de propriedade sobre os cativos que cruzavam as linhas de fronteira internacional deixou de figurar como prioridade das autoridades centrais. Esse fato em si pode servir para delinearmos uma nova perspectiva de entendimento acerca da delicada relação entre os poderes central e provincial (COSER, 2008), bem como dos significados assumidos pelas movimentações de fuga internacional de escravos, na segunda metade do século XIX.

No momento em que o Império do Brasil se via envolvido em uma guerra de grandes proporções contra o Paraguai e premido pelas pressões dos ribeirinhos superiores - Peru, Colômbia, Equador, Venezuela e Bolívia - para liberar a navegação dos rios interiores que faziam parte da bacia do Amazonas, as autoridades imperiais optaram por uma grande modificação de postura. $\mathrm{O}$ isolacionismo que, até aquele momento, norteava a conduta imperial em relação à navegação fluvial, dentro do subsistema andino, foi substituído por uma postura mais ativa do governo brasileiro ${ }^{74}$. Para tentar diminuir os níveis de animosidade com os Estados sul-americanos, o Ministério dos Estrangeiros resolveu enviar novas Missões Especiais para as repúblicas da Bolívia e Colômbia, com o intuito de definir as linhas de fronteiras e regular a questão da navegação.

As instruções para o desempenho da Missão Especial de Lopes Neto na Bolívia, em 1866, não traziam nenhuma novidade em relação ao que havia sido proposto em 1860, uma vez que a concessão do direito de navegar os rios continuou sendo utilizada como principal instrumento de barganha para a obtenção de maiores vantagens em

\footnotetext{
${ }^{73}$ AHI 317/04/15 - Instruções expedidas pelo Ministério dos Negócios Estrangeiros a João da Costa Rego Monteiro, Ministro Residente do Império do Brasil na Bolívia, em 12/3/1860.

${ }^{74}$ As pressões pela abertura da navegação do Amazonas e seus afluentes assumiram inúmeras formas, nos Estados limítrofes e dentro do próprio Brasil, desde a publicação de opúsculos panfletários que tencionavam sensibilizar a opinião pública, em relação aos benefícios que a medida traria até a defesa de teses acadêmicas. A seguir, elencamos alguns exemplos: ABNB. M403 IV. MARIA MONTEROLA, J. El rio Amazonas y las comarcas que forman su hoya, vertientes hacia el Atlantico. Lima: Impreso por Jose Maria Monterola, 1853; ABNB. M145-I - Tesis sobre la libre navegación de los ríos, pronunciada y sostenida por Angel Justiniano Carranza, en la Cátedra de Jurisprudencia de la Universidad de Buenos Aires, para recibir el grado de Doctor. Buenos Aires: Imprenta Americana, 1856; e, ABNB. M403 XIII El Madera y sus cabeceras. Cochabamba: Tipografia de Quevedo, 1861. [1 ${ }^{\mathrm{a}}$ Ed. en Belen del Pará,1861].

Revista Eletrônica da ANPHLAC, ISSN 1679-1061, n.15, p. 37-78, jul./dez. 2013.

http://revista.anphlac.org.br/
} 
relação às demarcações territoriais. Uma das recomendações iniciais do Ministério dos Negócios Estrangeiros ao negociador Lopes Neto esclarecia que, apesar das disposições do projeto de tratado de 1860 não oferecer as necessárias garantias de devolução dos cativos fugitivos, o governo imperial ainda pretendia retomar as negociações relativas à repatriação dos escravos. Entretanto, uma minuta formulada por Antônio Couto de Sá e Albuquerque, em 1866, modificou radicalmente o curso das pautas de interesse que seriam negociadas pelo Império brasileiro. Sá e Albuquerque (1866) deixa claro que a imprudente divulgação das disposições do Tratado da Tríplice Aliança havia criado suspeitas prejudiciais contra os partícipes da aliança e que, por esse motivo, o governo deixaria de insistir na tese de extradição dos prófugos escravos.

No que tange às cláusulas de extradição, o ajuste do Tratado de La Paz de Ayacucho, de 1867, acabou não representando (ou talvez o tenha feito em demasia) a preocupação do Ministério dos Estrangeiros com a preservação e (re)afirmação do direito de propriedade dos cidadãos brasileiros. Ao analisar o texto do tratado, percebemos que a ambiguidade foi uma de suas principais marcas, uma vez que o conteúdo dos cinco artigos relativos à parte extradicional não cita e nem sequer mencionada a existência da condição legal de escravo. A falta de compromisso do Estado brasileiro com a devolução dos cativos asilados também se manifesta nos procedimentos relativos aos pedidos de extradição, pois caberia exclusivamente ao Estado que recebesse o pedido de extradição, devolução ou repatriação a competência privativa de julgar a viabilidade do pedido. Dessa forma, notamos que a concessão ou não do asilo territorial, bem como da extradição ou repatriação dos cidadãos emigrados foi deixada em aberto no texto do tratado assinado entre Brasil e Bolívia, o que criou as condições ideais para que cada parte contratante prestasse a interpretação que melhor atendesse seus interesses.

\section{Referências bibliográficas}

ACCIOLY, H. Manual de direito internacional público. São Paulo: Saraiva, 1995.

ACQUARONE, A. C. Tratados de extradição: construção, atualidade e projeção do relacionamento bilateral brasileiro. Brasília: Instituto Rio Branco/FUNAG, 2003.

AGUIRRE, C. Agentes de su propia libertad: los esclavos de Lima y la desintegración de la esclavitud (1821-1854). Lima: Fondo Editorial de la Pontificia Universidad Católica del Perú, 1995.

Revista Eletrônica da ANPHLAC, ISSN 1679-1061, n.15, p. 37-78, jul./dez. 2013. http://revista.anphlac.org.br/ 
ALBARRACIN, B. Jordan de. Documentos para una historia del Derecho Constitucional Boliviano. La Paz: Talleres Gráficos "San Antonio", 1978.

ANDREWS, G. R. América afro-latina, 1800-2000. São Carlos: EdUFSCar, 2007.

ARAUJO, J. H. P. de. (Org.). Três ensaios sobre diplomacia. Brasília: Ministério das Relações Exteriores, 1989.

ARAÚJO, T. L. de. Escravidão, fronteira e liberdade: políticas de domínio, trabalho e luta em um contexto produtivo agropecuário (vila da Cruz Alta, província do Rio Grande de São Pedro, 1834-1884). Porto Alegre, 2008. Dissertação (Mestrado em História) - PPGH, UFRGS. Porto Alegre, 2008.

ARGUEDAS, A. Historia general de Bolivia, 1809-1921. (El proceso de la nacionalidad). La Paz: Ediciones "Puerta del Sol", 1967.

AZEVEDO, E. O direito dos escravos: lutas jurídicas e abolicionismo na província de São Paulo. Campinas: Editora da Unicamp, 2010.

BALDIBIESO, V. Abecia. Las relaciones internacionales en la Historia de Bolivia. La Paz: Editorial Los Amigos del Libro, 1986. t. I.

BERLIN, I. Gerações de cativeiro: uma história da escravidão nos Estados Unidos. Rio de Janeiro: Record, 2006.

BEZERRA NETO, J. M. Ousados e insubordinados: protesto e fugas de escravos na província do Grão-Pará (1840-1860). In: Topoi: Revista de História, v.2, p. 73-112, 2001.

BLACKBURN, R. A queda do escravismo colonial: 1776-1848. Rio de Janeiro: Record, 2002.

BORUCKI, A.; CHAGAS, K.; STALLA, N. Esclavitud y trabajo: un estudio sobre los afrodescendientes en la frontera uruguaya. Montevidéu: Mastergraf, 2009.

BRIDIKHINA, E. La mujer negra en Bolivia. La Paz: Ministerio de Desarrollo Humano: Subsecretaría de Asuntos de Género, 1995.

Coca, dinero o jornales (la situación económica y social de los exesclavos negros en Yungas del Norte, segunda mitad del siglo XIX). In: BARRAGAN, R.; CAJÍAS, D.; QAYUM, S. (Coord.). El siglo XIX. Bolivia y América Latina. La Paz: Instituto Francés de Estudios Andinos (IFEA); Muela del Diablo, 1997.

BROCKINGTON, L. G. Negros, indios y españoles en los Andes orientales: reivindicando el olvido de Mizque colonial (1550-1782). La Paz: Plural Editores, 2009.

CALDEIRA, N. C. Nas fronteiras da incerteza: as fugas internacionais de escravos no relacionamento diplomático do Império brasileiro com a República da Bolívia (18251867). Rio de Janeiro, 2007. Dissertação (Mestrado em História) - PPGHIS, UFRJ. Rio de Janeiro, 2007.

.; KOZLOWSKY, C. BOSISIO, R. Liberdade sem fronteiras: entre 1825 e 1867, ir para a Bolívia foi um caminho de esperança para alguns escravos, Revista de História, ano 6, nº 61, out. 2010.

Revista Eletrônica da ANPHLAC, ISSN 1679-1061, n.15, p. 37-78, jul./dez. 2013. http://revista.anphlac.org.br/ 
CARVALHO, J. M. de. A burocracia imperial: a dialética da ambiguidade. In: Dados: Revista de Ciências Sociais, v. 21, p. 7-31, 1979.

Civilização Brasileira, 2003.

A construção da ordem - Teatro das sombras. Rio de Janeiro:

CASTRO, J. B. de. A milícia cidadã: a Guarda Nacional de 1831 a 1850. São Paulo: Editora Nacional, 1979.

CERVO, A. L.; BUENO, C. História da política exterior do Brasil. Brasília: Editora da Universidade de Brasília, 2002.

CERVO, A. L. O Parlamento brasileiro e as relações exteriores (1826-1889). Brasília: Editora da Universidade de Brasília, 1981.

CHALHOUB, S. Visões da liberdade: uma história das últimas décadas da escravidão na corte. São Paulo: Companhia das Letras, 1990.

CHAVES, M. Eugenia. Color, género y esclavitud: mujeres esclavas y libertas en el Brasil y los países andinos (s. XVIII y XIX). In: Cadernos do CHDD, Ano IV, Número Especial, p. 133-157. 2005.

CHIARAMONTE, J. C. Nación y Estado en Iberoamérica: el lenguaje político en tiempos de las independencias. Buenos Aires: Sudamericana, 2004.

CLEMENTI, H. La abolición de la esclavitud en América Latina. Buenos Aires: La Pléyade, 1974.

CORREA FILHO, V. História de Mato Grosso. Rio de Janeiro: Instituto Nacional do Livro, 1969.

COSER, I. O conceito de federalismo e a ideia de interesse no Brasil do século XIX. In: Dados: Revista de Ciências Sociais, Rio de Janeiro, v.51, n.4, p. 941-981, 2008.

CUENCA, A. Pizarroso. La cultura negra en Bolivia. La Paz: Ediciones ISLA, 1977.

CUNHA, M. C. da. Antropologia do Brasil: mito, história, etnicidade. São Paulo: Brasiliense; EdUSP, 1986.

DAGET, S. A abolição do tráfico de escravos. In: AJAYI, J. F. A. (Ed.). História geral da África. Brasília: UNESCO, 2010. VI: África do século XIX à década de 1880. p. 77 104.

DAVIS, D. B. O problema da escravidão na cultura ocidental. Rio de Janeiro: Civilização Brasileira, 2001.

DURÁN, J. José. Trata de esclavos. Venta, reventa y arrendamiento de esclavos negros en Chuquisaca, 1826-1851. Encuentro Latinoamericano de Estudiantes de Historia, V. Actas... La Paz: Centro de Estudiantes de la Carrera de Historia de la Universidad Mayor de San Andrés, 2009. (CD-Rom).

ERGUETA, L. Antezana. Bolívia: historia de las Constituyentes. La Paz: Producciones CIMA, 2006.

FERREIRA, G. N. O rio da Prata e a consolidação do Estado imperial. São Paulo: Hucitec, 2006.

Revista Eletrônica da ANPHLAC, ISSN 1679-1061, n.15, p. 37-78, jul./dez. 2013.

http://revista.anphlac.org.br/ 
FRAGINALS, M. R. Moreno. La abolición de la esclavitud. In: VÁZQUEZ, J. Z. (directora del volumen VI). História general de América Latina: la construcción de las naciones latinoamericanas (1820-1870). Madrid: UNESCO, 2007. p. 465-481.

FRAGOSO, J.; FLORENTINO, M. O arcaísmo como projeto. Rio de Janeiro: Civilização Brasileira, 2001.

FONER, E. Free Soil, Free Labor, Free Men: the ideology of the republican party before the civil war. New York: Oxford University Press, 1995.

GALlARDO, J. E. De la rebeldía a la abolición. Buenos Aires: El Elefante Blanco, 2010.

GARCIA, E. V. (Org.). Diplomacia brasileira e política externa: documentos históricos (1493-2008). Rio de Janeiro: Contraponto, 2008.

GOES, S. S. Navegantes, bandeirantes, diplomatas: aspectos da descoberta do continente, da penetração do território brasileiro extra-Tordesilhas e do estabelecimento das fronteiras da Amazônia. Brasília: IPRI, 1991.

GOLDMAN, N.; SALVATORES, R. D. Caudillismos rioplatenses: nuevas miradas a un viejo problema. Buenos Aires: EUBEDA, Universidad de Buenos Aires, 1998.

GOLIN, T. A fronteira: os tratados de limites Brasil-Uruguai-Argentina, os trabalhos demarcatórios, os territórios contestados e os conflitos na bacia do Prata. Porto Alegre: L\&PM, 2004. V.2

GOMES, Flávio dos S. A hidra e os pântanos: mocambos, quilombos e comunidades de fugitivos no Brasil (séculos XVII-XIX). São Paulo: Unesp, 2005.

HANNERZ, U. Fluxos, fronteiras, híbridos: palavras-chave da antropologia transnacional. In: MANA: Publicação do Programa de Pós-graduação em Antropologia Social (PPGAS), v.3, n.1, p. 7-39, abr. 1997.

HENDRICK, G.; HENDRICK, W. Black refugees in Canada: accounts of escape during the era of slavery. North Carolina: McFarland \& Company, Inc., Publishers, 2010 .

HÜNEFELDT, C. Paying the price of freedom: family and labor among Lima`s slaves, 1800-1854. Berkeley: University of California Press, 1994.

IGLÉSIAS, F. Vida e Política, 1848-1868. In: HOLANDA, S. B. de. História geral da civilização brasileira. São Paulo: Difel, 1985. Tomo II, vol. 3. p. 9-112.

IZECKSOHN, V. Resistência ao recrutamento para o Exército durante as guerras Civil e do Paraguai. Brasil e Estados Unidos na década de 1860. In: Estudos Históricos, n.27, p. 84-109, 2001.

KLEIN, H. S. A concise History of Bolivia. New York: Columbia University Press, 2003.

LIMA, R. P. de. A nefanda pirataria de carne humana: escravizações ilegais e relações políticas na fronteira do Brasil meridional (1851-1868). Porto Alegre, 2010. Dissertação (Mestrado em História) - PPGH, UFRGS. Porto Alegre, 2010. 
LOVEMAN, B. El constitucionalismo andino, 1808-1880. In: MAIGUASHCA, J. (Ed.). Historia de América Andina. Quito: Universidad Andina Simón Bolívar, 2003. Volumen 5 - Creación de las repúblicas y formación de la nación. p. 277-288.

LYNCH, J. As repúblicas do Prata: da independência à Guerra do Paraguai. In: BETHELL, L. (Org.). História da América Latina: da independência a 1870, São Paulo: Editora da Universidade de São Paulo; Imprensa Oficial do Estado; Brasília: Fundação Alexandre de Gusmão, 2001. v. III. p. 625-692.

MACEDO, U. B. de. O visconde do Uruguai e o liberalismo doutrinário no Império. In: CRIPPA, A. (coord.). As ideias políticas no Brasil. São Paulo: Convívio, 1979. v. 1.

MÄDER, M. E. N. de S. Civilização e barbárie: a representação da nação nos textos de Sarmiento e do visconde do Uruguai. Niterói, 2006. Tese (Doutorado em História) PPGH, UFF. Niterói, 2006.

MACHADO, A. R. A. Bajo la sombra de la independencia: Gran Pará, la compleja red política en la crisis del Antiguo Régimen portugués. In: Revista Nuevo Mundo Mundos Nuevos [Online], Debates, 2013.

MACHADO, C. Na trama das vontades: negros, pardos e brancos na construção da hierarquia social do Brasil escravista. Rio de Janeiro: Apicuri, 2008.

MAGNOLI, D. O corpo da pátria: imaginação geográfica e política externa no Brasil (1808-1912). São Paulo: Editora da Universidade Estadual Paulista; Moderna, 1997.

MALLON, F. E. Las sociedades indígenas frente al nuevo orden. In: História general de América Latina: la construcción de las naciones latinoamericanas (1820-1870). Madrid: UNESCO, 2004. p. 251-271.

MAMIGONIAN, B.; GRINBERG, K. Apresentação do dossiê: "Para inglês ver"? Revisitando a Lei de 1831. In: Estudos Afro-Asiáticos, Ano 29, n. 1/2/3, p. 87-90, jan.dez. 2007.

MARQUESE, R. de B. Feitores do corpo, missionários da mente: senhores, letrados e o controle dos escravos nas américas, 1660-1860. São Paulo: Companhia das Letras, 2004.

MEIRELES, D. M. Guardiães da fronteira: rio Guaporé, século XVIII. Petrópolis: Vozes, 1989.

MELO, A. B. de A. e. Os programas dos partidos e o Segundo Império. Brasília: Senado Federal; Rio de Janeiro: Fundação Casa de Rui Barbosa, 1979.

MENDONÇA, J. N. A arena jurídica e a luta pela liberdade. In: SCHWARCZ, L. M.; REIS, L. V. (Orgs.). Negras imagens. São Paulo: Edusp, 1996. p. 117-137.

MILZA, P. Política interna e política externa. In: RÉMOND, R. (Org.). Por uma história política. Rio de Janeiro: UFRJ, 1996. p. 365-399.

MITRE, A. Estado, nação e território na Bolívia oligárquica, 1850-1914. In: PAMPLONA, M.; MÄDER, M. E. (Orgs.). Revoluções de independências $e$ nacionalismos nas Américas: Peru e Bolívia. São Paulo: Paz e Terra, 2010. V. 4. p.193237.

MONTESQUIEU, C. O espírito das leis. São Paulo: Martins Fontes, 2000.

Revista Eletrônica da ANPHLAC, ISSN 1679-1061, n.15, p. 37-78, jul./dez. 2013.

http://revista.anphlac.org.br/ 
MOURA, C. Rebeliões da senzala: quilombos, insurreições, guerrilhas. Porto Alegre: Mercado Aberto, 1988.

ORTIZ, M. Portugal. La esclavitud negra en las epocas colonial y nacional de Bolivia. La Paz: Instituto boliviano de cultura, 1977.

PALM, P. R. A abertura do rio Amazonas à navegação internacional e o parlamento brasileiro. Brasília: Fundação Alexandre de Gusmão, 2009.

PARRON, T. A política da escravidão no Império do Brasil, 1826-1865. Rio de Janeiro: Civilização Brasileira, 2011.

PEABODY, S. There are no slaves in France: the political culture of race and slavery in the Ancien Régime. New York: Oxford University Press, 1996.

PETIZ, S. Buscando a liberdade: as fugas de escravos da província de São Pedro para o além-fronteira (1811-1851). Passo Fundo: UPF, 2006.

PIMENTA, J. P. G. Estado e nação no fim dos Impérios ibéricos no Prata: 1808-1828. São Paulo: Hucitec, 2006.

PINTO, A. Pereira. Apontamentos para o direito internacional ou Colecção completa dos Tratados celebrados pelo Brazil com differentes nações estrangeiras. Rio de Janeiro: F. L. Pinto \& C. ${ }^{\text {a }}, 1865$. v. I.

PRADO, M. L. C. Repensando a história comparada da América Latina, Revista de História, $\mathrm{n}^{\circ} 153$, p. 11-33, $2^{\circ}$ semestre 2005.

ORÍAS, P. A. Revilla. Ni yo ni mis compañeros hemos venido presos, sino espontáneamente a presentarnos y vindicarnos: móviles y sentidos marginados de la más que bicentenaria lucha por la libertad en Charcas. In: CAMBA: Revista Municipal de Cultura, año 3, n. 4, p. 32-33, mayo de 1993.

RICCI, M. Cabanagem, cidadania e identidade revolucionária: o problema do patriotismo na Amazônia entre 1835 e 1840. In: Tempo: Revista do Departamento de História da UFF, v.11, n.22 (Cidadania e Pobreza), p. 22-30, jan. 2007.

RODAS, A. Crespo. Esclavos negros en Bolivia. La Paz: Librería Editorial "G.U.M.”, $\mathrm{s} / \mathrm{d}$.

RODRIGUES, A. E. M.; FALCON, F.; NEVES, M. A Guarda Nacional no Rio de Janeiro (1831-1918). Rio de Janeiro: PUCRJ, 1981.

RODRIGUES, M. C. A extradição no direito brasileiro e na legislação comparada. Rio de Janeiro: Imprensa Nacional, 1930. t. I.

ROUSSEAU, Jean-Jacques. Do contrato social. São Paulo: Abril, 1978.

RUSSOMANO, G. M. A extradição no direito internacional e no direito brasileiro. São Paulo: Revista dos Tribunais, 1981.

SAFFORD, F.; JACOBSEN, N. Las economías de la América Andina, 1830-1885. In: MAIGUASHCA, J. (Ed.). Historia de América Andina. Quito: Universidad Andina Simón Bolívar, 2003. Volumen 5 - Creación de las repúblicas y formación de la nación. p. 29-92.

SALLES, V. O negro no Pará sob o regime da escravidão. Belém: Secult; Minc, 1988.

Revista Eletrônica da ANPHLAC, ISSN 1679-1061, n.15, p. 37-78, jul./dez. 2013.

http://revista.anphlac.org.br/ 
SALMORAL, M. Lucena. Los códigos negros de la América Española. Madrid: Ediciones UNESCO; Universidad de Alcalá, 1996.

SANTOS, L. C. V. O império e as repúblicas do Pacífico: as relações do Brasil com Chile, Bolívia, Peru, Equador e Colômbia (1822-1889). Curitiba: UFPR, 2002.

SANZ, J. A. Ovando. La invasión brasileña a Bolivia en 1825. La Paz: Libreria Editorial Juventud, 1986.

SECKINGER, R. Politcs in Mato Grosso, 1821-1851. Berkeley, 1970. Tese (Doutorado em História) - University of Florida. Berkeley, 1970.

SCHERER, J. de S. Experiências de busca da liberdade: alforria e comunidade africana em Rio Grande. São Leopoldo, 2008. Dissertação (Mestrado em História) - PPG, UNISINOS. São Leopoldo, 2008.

SOARES, A. T. História da formação das fronteiras do Brasil. Rio de Janeiro: Conquista, 1975.

SOUZA, J. A. S. de. Um diplomata do Império (barão da Ponte Ribeiro). São Paulo: Companhia Editora Nacional, 1952.

SVAMPA, M. La dialéctica entre lo nuevo y lo viejo: sobre los usos e nociones del caudillismo en la Argentina durante el siglo XIX. In: GOLDMAN, N.; SALVATORES, R. D. (Comp.). Caudillismos rioplatenses: nuevas miradas a un viejo problema. Buenos Aires: EUBEDA, Universidad de Buenos Aires, 1998. p. 51-81.

PIMENTA, J. P. G. Estado e nação no fim dos Impérios ibéricos no Prata: 1808-1828. São Paulo: Hucitec, 2006.

THIESSEN-REILY, H. O nacionalismo caudilhista na Bolívia. In: PAMPLONA, M.; DOYLE, D. H. (Orgs.). Nacionalismo no Novo Mundo: a formação dos Estados-nação no século XIX. Rio de Janeiro: Record, 2008. p. 355-376.

TRIGO, C. Félix Derecho Constitucional Boliviano. La Paz: Fondo Editorial de la Biblioteca y Archivo Histórico del Honorable Congreso Nacional, 2003.

UGARTE, M. Galindo de. Constituciones bolivianas comparadas (1826-1967). La Paz: Editorial "Los Amigos del Libro", 1991.

VALCUENDE, J. M. (Coord.). História e memórias das três fronteiras: Brasil, Peru e Bolívia. São Paulo: EDUC, 2009.

VALLADÃO, H. Direito internacional público. Rio de Janeiro: Livraria Freitas Bastos, 1977. v. 3.

VANGELISTA, C. Las relaciones hispano-portuguesas en el norte de Mato Grosso, siglos XVIII-XIX. In: Anos 90, nº 9, Porto Alegre, p. 33-55, julho 1998.

VAZQUEZ-MACHICADO, H. Para una historia de los limites entre Bolivia y el Brasil. La Paz: Libreria Editorial "Juventud”, 1990.

VIANNA, H. História diplomática do Brasil. São Paulo: Edições Melhoramentos, s/d.

VILLAMARÍN, J. La mano de obra nativa y la continuación de los patrones "coloniales" en los siglos XIX y XX. In: CARMAGNANI, M.; CHÁVEZ, A. H.;

Revista Eletrônica da ANPHLAC, ISSN 1679-1061, n.15, p. 37-78, jul./dez. 2013.

http://revista.anphlac.org.br/ 
ROMANO, R. (Coord.). Para una historia de América. III. Los nudos (2). México: Fondo de Cultura Económica, 1999. p. 65-68.

VOLPATO, L. A conquista da terra no universo da pobreza: formação da fronteira oeste do Brasil, 1719-1819. São Paulo: Hucitec; Brasília: INL, 1987.

Cativos do sertão: vida cotidiana e escravidão em Cuiabá em 18501888. Campo Grande: Editora da UFMS, 1993.

WEGNER, R. A conquista do oeste: a fronteira na obra de Sergio Buarque de Holanda. Belo Horizonte: Editora UFMG, 2000.

ZUBARAN, M. A. Escravidão e liberdade nas fronteiras do Rio Grande do Sul (18601880): o caso da lei de 1831. In: Estudos Ibero-Americanos, v.XXXII, n.2, p. 119-132, dez. 2006.

Revista Eletrônica da ANPHLAC, ISSN 1679-1061, n.15, p. 37-78, jul./dez. 2013.

http://revista.anphlac.org.br/ 